Nature

February 2018, Volume 554 Pages 515-518

http://dx.doi.org/10.1038/nature25493

Archimer

http://archimer.ifremer.fr/doc/00426/53783/

(c) 2018 Macmillan Publishers Limited, part of Springer Nature. All rights

reserved.

\title{
Meridional overturning circulation conveys fast acidification to the deep Atlantic Ocean
}

\author{
Perez Fiz F ${ }^{1,}{ }^{*}$, Fontela Marcos ${ }^{1}$, Garcia-Ibanez Maribel I. ${ }^{1}$, Mercier Herle ${ }^{2}$, Velo Anton ${ }^{1}$, \\ Lherminier Pascale ${ }^{3}$, Zunino Patricia ${ }^{2}$, De La Paz Mercedes ${ }_{1}^{1}$, Alonso-Pérez Fernando ${ }^{1}$,' \\ Guallart Elisa F. ${ }^{1}$, Padin Xose A. ${ }^{1}$
}

\author{
1 Instituto Investigaciones Marinas (IIM, CSIC), calle Eduardo Cabello, 6, 36208, Vigo, Spain \\ ${ }^{2}$ Centre National de la Recherche Scientifique (CNRS), Ifremer, Université de Brest, Institut de \\ Recherche pour le Développement, Laboratoire d'Océanographie Physique et Spatiale (LOPS), Centre \\ Ifremer de Bretagne, 29280, Plouzané, France \\ * Corresponding author : Fiz F. Perez, email address : $\underline{\text { fiz.perez@iim.csic.es }}$
}

\begin{abstract}
:
Since the Industrial Revolution, the North Atlantic Ocean has been accumulating anthropogenic carbon dioxide (CO2) and experiencing ocean acidification1, that is, an increase in the concentration of hydrogen ions (a reduction in $\mathrm{pH}$ ) and a reduction in the concentration of carbonate ions. The latter causes the 'aragonite saturation horizon'-below which waters are undersaturated with respect to a particular calcium carbonate, aragonite-to move to shallower depths (to shoal), exposing corals to corrosive waters2,3. Here we use a database analysis to show that the present rate of supply of acidified waters to the deep Atlantic could cause the aragonite saturation horizon to shoal by 1,0001,700 metres in the subpolar North Atlantic within the next three decades. We find that, during 19912016, a decrease in the concentration of carbonate ions in the Irminger Sea caused the aragonite saturation horizon to shoal by about 10-15 metres per year, and the volume of aragonite-saturated waters to reduce concomitantly. Our determination of the transport of the excess of carbonate over aragonite saturation (xc[CO32-])-an indicator of the availability of aragonite to organisms-by the Atlantic meridional overturning circulation shows that the present-day transport of carbonate ions towards the deep ocean is about 44 per cent lower than it was in preindustrial times. We infer that a doubling of atmospheric anthropogenic $\mathrm{CO} 2$ levels-which could occur within three decades according to a 'business-as-usual scenario' for climate change4-could reduce the transport of xc[CO32-] by 6479 per cent of that in preindustrial times, which could severely endanger cold-water coral habitats. The Atlantic meridional overturning circulation would also export this acidified deep water southwards, spreading corrosive waters to the world ocean.
\end{abstract}


30 Atmospheric $\mathrm{CO}_{2}$ has increased from 280 to 400 parts per million (ppm) since the

31 Industrial Revolution. The global ocean has captured $\sim 30 \%$ of this anthropogenic $\mathrm{CO}_{2}$

$32\left(\mathrm{C}_{\text {ant }}\right)$, acting as a climate regulator ${ }^{1}$. This $\mathrm{CO}_{2}$ absorption has led to a decrease in seawater 
$\mathrm{pH}\left(\sim 0.12\right.$ units) and in the supersaturation of $\mathrm{CaCO}_{3}$ (effects collectively known as ocean acidification - OA). OA can particularly affect marine calcifiers ${ }^{1}$ by favouring the solubility of $\mathrm{CaCO}_{3}$-based shells and skeletons ${ }^{2}$. Notably, deep cold-water coral (CWC) reefs formed by scleractinian corals, such as the ecosystem engineer specie Lophelia pertusa, are highly vulnerable to $\mathrm{OA}^{3}$. The global distribution of CWC seems to be partly limited by the depth of the ASH, which is the boundary between aragonite-stable waters above and dissolution-prone waters below ${ }^{5}$. In pre-industrial times, more than $95 \%$ of $\mathrm{CWC}$ locations were found above the $\mathrm{ASH}^{6}$, providing evidence that environments located below the ASH are hostile to CWC growth. In the North Pacific (NP; Fig. 1a), where the ASH is only $500 \mathrm{~m} \mathrm{deep}^{7}$, the distribution of aragonitic CWC is patchy and CWC do not develop to large deep reef frameworks that are abundant in the North Atlantic (NA) ${ }^{8}$ where the ASH is deeper than $2000 \mathrm{~m}$. OA is causing the ASH to shoal, thus exposing CWC to $\mathrm{CaCO}_{3}$ undersaturation. Although laboratory experiments suggest that adult L. pertusa can acclimatize to $\mathrm{CaCO}_{3}$ undersaturation ${ }^{9,10}$, the long-term survival of $\mathrm{CWC}$ reefs in undersaturated water is questioned because $L$. pertusa skeleton becomes weaker when exposed yearlong to future OA scenarios ${ }^{10}$, and the dead skeletal framework that supports the reef itself is likely to dissolve in undersaturated waters ${ }^{11}$.

To determine the degree of aragonite saturation of the world ocean waters, we calculated $\mathrm{xc}\left[\mathrm{CO}_{3}{ }^{2-}\right]$ (in $\mu \mathrm{mol} \mathrm{kg}{ }^{-1}$ ) by using quality-controlled global datasets of marine $\mathrm{CO}_{2}$ system measurements ${ }^{12,13}$. Positive (negative) $x\left[\mathrm{CO}_{3}{ }^{2-}\right]$ indicates aragonite supersaturated (undersaturated) waters (see Methods). High positive ${ }_{\mathrm{xc}}\left[\mathrm{CO}_{3}{ }^{2-}\right]$ values occur in the NA while negative values occur in the NP, which is consistent with the distribution of $\mathrm{CWC}^{14}$ below 1,000 m (Fig. 1a). About $61 \%$ (78\%) of CWC found deeper than 1,000 m (1,500 m) are located in the NA where $\mathrm{xc}_{\mathrm{c}}\left[\mathrm{CO}_{3}{ }^{2-}\right]>0$, with an average ${ }_{\mathrm{xc}}\left[\mathrm{CO}_{3}{ }^{2-}\right]$ of $24.5 \mu \mathrm{mol} \mathrm{kg}^{-1}(15$ $\mu \mathrm{mol} \mathrm{kg}{ }^{-1}$ ) that is half the natural (pre-industrial) $x\left[\mathrm{CO}_{3}{ }^{2-}\right]$ (see Extended Data Table 1). The AMOC created the favourable conditions for CWC growth found in the NA by conveying ventilated waters loaded with relatively high $\mathrm{pH}$ and positive ${ }_{\mathrm{xc}}\left[\mathrm{CO}_{3}{ }^{2-}\right]$ to the deep Atlantic Ocean. 
In the centre of the Irminger Sea (Fig. 1b), winter deep-convection and associated deep injection of OA recorded during 1991-2016 showed a constant increase in $\mathrm{C}_{\text {ant }}$ from 30 to $50 \mu \mathrm{mol} \mathrm{kg}{ }^{-1}$ in the ventilated Subpolar Mode Water (Fig. 2a). During the same period, the atmospheric $\mathrm{C}_{\text {ant }}$ grew from 85 to $123 \mathrm{ppm}$. A thick layer of low salinity $(<34.91)$ traces the strong convection events that occurred during the first half of the 1990s and during 2014-2016. During those strong convection events, Subpolar Mode Water was ventilated down to $1,500 \mathrm{~m}$, showing high temporal variability and no indication of a slowing-down of deep convection ${ }^{15,16}$. Present-day surface ocean shows an increase of about $30 \%$ in $\left[\mathrm{H}^{+}\right]$ with respect to the natural (pre-industrial) value ${ }^{1}$. At the centre of the Irminger Sea, the $\left[\mathrm{H}^{+}\right]$increase affects a layer $\sim 1,500 \mathrm{~m}$ thick (Fig. 2c), the deepest signal of direct injection of OA ever observed. Since 2002, the anthropogenic perturbation caused a deepening of the isolines of 25 and $30 \%$ of anthropogenic $\left[\mathrm{H}^{+}\right]$from surface to $1,500 \mathrm{~m}$. The isolines of $\mathrm{xc}\left[\mathrm{CO}_{3}{ }^{2-}\right]$ progressively ascend at about $10-15 \mathrm{~m} \mathrm{yr}^{-1}$ (Fig. 2b), with some slightly faster ascension periods related to deep convection events (arrows in Fig. 2b). The effect of these deep convection events is buffered by the partial balance between the increase in the anthropogenic $\left[\mathrm{H}^{+}\right]$and the decrease in the natural $\left[\mathrm{H}^{+}\right]($due to the removal of the natural $\mathrm{CO}_{2}$ accumulated in old waters by remineralisation of organic matter) (Fig. 2c). Because of this biogeochemical feedback, the decrease in ${ }_{\mathrm{xc}}\left[\mathrm{CO}_{3}{ }^{2-}\right]$ and the associated shoaling of the ASH are only weakly sensitive to the intensity of the deep convection.

West of $20^{\circ} \mathrm{W}$ in the subpolar NA (SPNA), the ASH observed in 2016 is $200-500 \mathrm{~m}$ shallower than the pre-industrial ASH (Fig. 1c). Along the 2016 Ovide section, the $25 \mu \mathrm{mol}$ $\mathrm{kg}^{-1}$ isoline of the present-day ${ }_{\mathrm{xc}}\left[\mathrm{CO}_{3}{ }^{2-}\right]$ runs close to the $50 \mu \mathrm{mol} \mathrm{\textrm {kg } ^ { - 1 }}$ isoline of natural ${ }_{x c}\left[\mathrm{CO}_{3}{ }^{2-}\right]$, indicating a $50 \%$ decrease in the availability of $\mathrm{CO}_{3}{ }^{2-}$ for deep $\mathrm{CWC}$. These changes reflect the spreading of newly ventilated Subpolar Mode Water with low xc $\left[\mathrm{CO}_{3}{ }^{2-}\right]$ from the Irminger Sea to the Iceland basin.

The 2002-2016 AMOC mean transport across the Ovide section ${ }^{17}$ was $16.2 \pm 0.8 \mathrm{~Sv}(1 \mathrm{~Sv}$ $=1$ million $\left.\mathrm{m}^{3} \mathrm{~s}^{-1}\right)$. The upper and lower limbs of the AMOC showed contrasted ${ }_{\mathrm{xc}}\left[\mathrm{CO}_{3}{ }^{2-}\right]$ (Fig. 1c) and $\mathrm{C}_{\text {ant }}$ (Extended Data Fig. 1), with average ${ }_{x c}\left[\mathrm{CO}_{3}{ }^{2-}\right]$ values of $61 \pm 2 \mu \mathrm{mol} \mathrm{kg}^{-1}$ and $28 \pm 3 \mu \mathrm{mol} \mathrm{kg} \mathrm{kg}^{-1}$, respectively. The upper limb of the AMOC flows northwards (above 
the isopycnal $\sim 1,032.15 \mathrm{~kg} \mathrm{~m}^{-3}$ ), transporting 1,064 $\mathrm{kmol} \mathrm{s}^{-1}$ of $\mathrm{xc}_{\mathrm{xc}}\left[\mathrm{CO}_{3}{ }^{2-}\right]$ (Fig. 3). About $40 \%$ of this transport ( $435 \mathrm{kmol} \mathrm{s}^{-1}$ ) subducted into the lower limb of the AMOC in the SPNA, while the remaining $60 \%$ was exported to the Nordic Seas ${ }^{18,19}$. These $x c\left[\mathrm{CO}_{3}{ }^{2-}\right]$ transport values are between 33 and $44 \%$ lower than the transport of natural $x\left[\mathrm{CO}_{3}{ }^{2-}\right]$ because natural $\mathrm{xc}_{\mathrm{x}}\left[\mathrm{CO}_{3}{ }^{2-}\right]$ values in the upper and lower limbs of the AMOC $(90 \pm 2$ and 49 $\pm 4 \mu \mathrm{mol} \mathrm{kg}{ }^{-1}$, respectively) are much larger than the present-day values (61 \pm 2 and $28 \pm 3$ $\mu \mathrm{mol} \mathrm{kg}{ }^{-1}$, respectively). By vertically transporting lower $\mathrm{xc}\left[\mathrm{CO}_{3}{ }^{2-}\right]$ with respect to preindustrial, the AMOC is responsible for the decrease in $\mathrm{pH}$ and ${ }_{x c}\left[\mathrm{CO}_{3}{ }^{2-}\right]$ in the deep NA.

IPCC projections ${ }^{20}$ indicate that a warming of about $2^{\circ} \mathrm{C}$ will be reached when atmospheric $\mathrm{CO}_{2}$ rises to $480-520$ ppm (Extended Data Fig. 2) (i.e. a $\mathrm{CO}_{2}$ excess over pre-industrial values or $\mathrm{C}_{\text {ant }}$ of 200-240 ppm). These figures are about two-fold the present-day anthropogenic perturbation in temperature and $\mathrm{CO}_{2}\left(1^{\circ} \mathrm{C}\right.$ warming ${ }^{21}$ and $\mathrm{C}_{\text {ant }}$ of $100-120$ $\mathrm{ppm})$. The ${ }_{\mathrm{xc}}\left[\mathrm{CO}_{3}{ }^{2-}\right]$ for a doubling of the atmospheric $\mathrm{C}_{\text {ant }}$ was inferred by adding 0.72 times present-day marine $\mathrm{C}_{\text {ant }}$ (Extended Data Fig. 1) to the marine $\left[\mathrm{CO}_{2}\right]$ observed in 2002-2016 and assuming that $C_{\text {ant }}$ changes follow the transient steady approximation ${ }^{22,23}$ (see Methods). The projected slow-down of the deep convection by the end of the century should not invalidate this approach because, as concluded above, the decrease in ${ }_{x c}\left[\mathrm{CO}_{3}{ }^{2-}\right]$ is only weakly sensitive to the intensity of the deep convection. When doubling the atmospheric $\mathrm{C}_{\text {ant }}$, the volume of aragonite-saturated deep waters in the Iceland basin and the Irminger Sea decreases dramatically as shown by the 1,000-1,700 m shoaling with respect to pre-industrial depths of both the ASH and the isolines of $25-50 \mu \mathrm{mol} \mathrm{kg}^{-1} \mathrm{of}_{\mathrm{xc}}\left[\mathrm{CO}_{3}{ }^{2-}\right]$ (Fig. 1c). A most striking feature is the vanishing of the vertical gradient of $\left[\mathrm{H}^{+}\right]$caused by OA (Extended Data Fig. 3), due to the relatively rapid deep injection of $\mathrm{C}_{\text {ant }}$ by the AMOC, leading to the homogenization of the $\mathrm{pH}$ in the whole water column. The disappearance of the vertical gradient of $\mathrm{pH}$ would lead to a substantial weakening of the vertical gradient of $\mathrm{xc}\left[\mathrm{CO}_{3}{ }^{2-}\right]$.

We find that doubling the atmospheric $\mathrm{C}_{\text {ant }}$ could result in $70 \%$ of the $\mathrm{CWC}$ deeper than $1,500 \mathrm{~m}$ in the NA living below the $\mathrm{ASH}$ and being exposed to negative ${ }_{\mathrm{xc}}\left[\mathrm{CO}_{3}{ }^{2-}\right]$

(Extended Data Table 1). An average reduction of $75 \%$ in $\mathrm{xc}_{\mathrm{C}}\left[\mathrm{CO}_{3}{ }^{2-}\right]$ with respect to pre- 
industrial would be observed for the CWC living below $1,000 \mathrm{~m}$. This may occur as soon as 2050 in a business as usual scenario (SSP5, see Extended Data Fig. 2) ${ }^{4}$. Our data-based results are in line with the IPCC projections ${ }^{24}$ that point to OA being a serious threat for deep $(>1,000 \mathrm{~m}) \mathrm{CWC}$ habitats in the NA by 2100 . However, most recent model studies showed large discrepancies in their estimates of the extent of CWC habitats that could be exposed to corrosive waters by the end of the century. The proportion of CWC projected to live below the ASH varies between $23 \%$ and $70 \%$ of its present-day area for the most recent simulations using business as usual concentration pathways ${ }^{6,25}$. The portion could reach $85 \%$ of the Northeast Atlantic CWC surfaces by $2060^{26}$. Our findings support the latter projection. We show that the water masses of the lower limb of the AMOC are becoming more acidic. Those water masses are ventilating the deep layers of the world ocean and propagating the acidification threat to the $\mathrm{CWC}$ habitats of the world ocean. We estimate that for a doubling of the atmospheric $\mathrm{C}_{\text {ant }}$, the average ${ }_{\mathrm{xc}}\left[\mathrm{CO}_{3}{ }^{2-}\right]$ below $1,000 \mathrm{~m}$ would become negative for the world ocean (Extended Data Table 1), indicating that most of the deep CWC habitats of the world ocean may be exposed to corrosive waters by 2050 .

Models predict a slow-down of $25 \%$ of the mid-latitude AMOC by the end of the present century $^{20}$, which would lead directly to decreasing volume of the southward export of waters with negative ${ }_{x c}\left[\mathrm{CO}_{3}{ }^{2-}\right]$ to the global deep ocean. However, the AMOC reduction would also lead to a reduction of the ventilation of the deep ocean at mid-latitudes and, therefore, to a reduction of the dissolved oxygen and $\mathrm{pH}$ through remineralisation processes $^{27-29}$. Therefore, future AMOC slow-down could contribute to worsen the acidification threats for deep CWC.

\section{REFERENCES:}

1. Gattuso, J.-P. et al. Contrasting futures for ocean and society from different anthropogenic $\mathrm{CO}_{2}$ emissions scenarios. Science 349, aac4722 (2015).

2. Pörtner, H.-O. et al. Ocean systems. in Climate Change 2014: Impacts, Adaptation, and Vulnerability. Part A: Global and Sectoral Aspects. Contribution of Working Group II to the Fifth Assessment Report of the Intergovernmental Panel of Climate Change (eds. Field, C. B. et al.) 411-484 (Cambridge University Press, 2014). 
3. Roberts, J. M. Cold-Water Corals: The Biology and Geology of Deep-Sea Coral Habitats. (Cambridge University Press, 2009).

4. Riahi, K. et al. The Shared Socioeconomic Pathways and their energy, land use, and greenhouse gas emissions implications: An overview. Glob. Environ. Change 42, $153-$ 168 (2017).

5. Tittensor, D. P., Baco, A. R., Hall-Spencer, J. M., Orr, J. C. \& Rogers, A. D. Seamounts as refugia from ocean acidification for cold-water stony corals. Mar. Ecol. 31, 212-225 (2010).

6. Guinotte, J. M. et al. Will human-induced changes in seawater chemistry alter the distribution of deep-sea scleractinian corals? Front. Ecol. Environ. 4, 141-146 (2006).

7. Jiang, L.-Q. et al. Climatological distribution of aragonite saturation state in the global oceans. Glob. Biogeochem. Cycles 29, 1656-1673 (2015).

8. Feely, R. A. et al. Impact of Anthropogenic $\mathrm{CO}_{2}$ on the $\mathrm{CaCO}_{3}$ System in the Oceans. Science 305, 362-366 (2004).

9. Maier, C., Hegeman, J., Weinbauer, M. G. \& Gattuso, J.-P. Calcification of the coldwater coral Lophelia pertusa, under ambient and reduced pH. Biogeosciences 6, 16711680 (2009).

10. Hennige, S. J. et al. Hidden impacts of ocean acidification to live and dead coral framework. Proc. R. Soc. B Biol. Sci. 282, 20150990 (2015).

11. Thresher, R., Tilbrook, B., Fallon, S., Wilson, N. \& Adkins, J. Effects of chronic low carbonate saturation levels on the distribution, growth and skeletal chemistry of deepsea corals and other seamount megabenthos. Mar. Ecol. Prog. Ser. 442, 87-99 (2011).

12. Olsen, A. et al. The Global Ocean Data Analysis Project version 2 (GLODAPv2) - an internally consistent data product for the world ocean. Earth Syst. Sci. Data 8, 297-323 (2016).

13. Key, R.M. et al. Global Ocean Data Analysis Project, Version 2 (GLODAPv2), ORNL/CDIAC-162, ND-P093. (Carbon Dioxide Information Analysis Center (CDIAC), 2015).

14. Freiwald, A., Fosså, H., Grehan, A., Koslow, T. \& Roberts, J. M. Cold-water coral reefs: out of sight-no longer out of mind. 22, (UNEP-WCMC, Cambridge, UK, 2004). 
15. Pickart, R. S. et al. Convection in the Western North Atlantic Sub-Polar Gyre: Do Small-Scale Wind Events Matter? in Arctic-Subarctic Ocean Fluxes 629-652 (Springer, Dordrecht, 2008).

16. Yashayaev, I. \& Loder, J. W. Further intensification of deep convection in the Labrador Sea in 2016. Geophys. Res. Lett. 44, 1429-1438 (2017).

17. Mercier, H. et al. Variability of the meridional overturning circulation at the Greenland-Portugal OVIDE section from 1993 to 2010. Prog. Oceanogr. 132, 250-261 (2015).

18. Jeansson, E. et al. The Nordic Seas carbon budget: Sources, sinks, and uncertainties. Glob. Biogeochem. Cycles 25, GB4010 (2011).

19. Pérez, F. F. et al. Atlantic Ocean $\mathrm{CO}_{2}$ uptake reduced by weakening of the meridional overturning circulation. Nat. Geosci. 6, 146-152 (2013).

20. Climate Change 2013 - The Physical Science Basis: Working Group I Contribution to the Fifth Assessment Report of the Intergovernmental Panel on Climate Change. (Cambridge University Press, 2014).

21. Le Quéré, C. The implications of COP21 for our future climate. Public Health Rev. 37, 29 (2016).

22. Tanhua, T. et al. Changes of anthropogenic $\mathrm{CO}_{2}$ and CFCs in the North Atlantic between 1981 and 2004. Glob. Biogeochem. Cycles 20, GB4017 (2006).

23. Steinfeldt, R., Rhein, M., Bullister, J. L. \& Tanhua, T. Inventory changes in anthropogenic carbon from 1997-2003 in the Atlantic Ocean between $20^{\circ} \mathrm{S}$ and $65^{\circ} \mathrm{N}$. Glob. Biogeochem. Cycles 23, GB3010 (2009).

24. Hoegh-Guldberg, O. et al. The Ocean. in Climate Change 2014: Impacts, Adaptation, and Vulnerability. Part B: Regional Aspects. Contribution of Working Group II to the Fifth Assessment Report of the Intergovernmental Panel of Climate Change (eds. Barros, V. R. et al.) 1655-1731 (Cambridge University Press, 2014).

25. Gehlen, M. et al. Projected pH reductions by 2100 might put deep North Atlantic biodiversity at risk. Biogeosciences 11, 6955-6967 (2014).

26. Jackson, E. L., Davies, A. J., Howell, K. L., Kershaw, P. J. \& Hall-Spencer, J. M. Future-proofing marine protected area networks for cold water coral reefs. ICES J. Mar. Sci. J. Cons. 71, 2621-2629 (2014). 
27. Tagklis, F., Bracco, A. \& Ito, T. Physically driven Patchy O2 Changes in the North Atlantic Ocean simulated by the CMIP5 Earth System Models. Glob. Biogeochem. Cycles doi:10.1002/2016GB005617

28. Resplandy, L., Bopp, L., Orr, J. C. \& Dunne, J. P. Role of mode and intermediate waters in future ocean acidification: Analysis of CMIP5 models. Geophys. Res. Lett. 40, 3091-3095 (2013).

29. Fontela, M., García-Ibáñez, M. I., Hansell, D. A., Mercier, H. \& Pérez, F. F. Dissolved Organic Carbon in the North Atlantic Meridional Overturning Circulation. Sci. Rep. 6, 26931 (2016).

\section{Methods:}

\section{Aragonite saturation and carbonate ion excess}

Aragonite is one of the $\mathrm{CaCO}_{3}$ metastable forms used by calcifying marine organisms to build their shells ${ }^{30,31}$. A measure of the bioavailability of aragonite is the in situ degree of aragonite saturation $\left(\Omega_{\mathrm{A}}\right)$ given by Eq. (1):

$$
\Omega_{A}=\frac{\left[\mathrm{Ca}^{2+}\right]\left[\mathrm{CO}_{3}^{2-}\right]_{i s}}{K_{A}}
$$

where $\left[\mathrm{Ca}^{2+}\right]$ is the concentration of the major ion calcium, $\left[\mathrm{CO}_{3}{ }^{2-}\right]$ is the concentration of the carbonate ion, and $\mathrm{K}_{\mathrm{A}}$ is the $\mathrm{CaCO}_{3}$ aragonite solubility product. Subscript "is" denotes at in situ temperature and pressure conditions. $\left[\mathrm{Ca}^{2+}\right]$ is conservative and is obtained from salinity (S) through Eq. $(2)^{32}$ :

$$
\left[\mathrm{Ca}^{2+}\right]=0.01028 \times \mathrm{S} / 35
$$

Another convenient measure of the aragonite saturation is the difference between $\left[\mathrm{CO}_{3}{ }^{2-}\right]_{\text {is }}$ and the $\left[\mathrm{CO}_{3}{ }^{2-}\right]$ at saturation $\left(\left[\mathrm{CO}_{3}{ }^{2-}\right]_{\operatorname{sat}(\Omega \mathrm{A}=1)}\right)$, which is the excess of carbonate ion concentration over aragonite saturation $\left(\mathrm{xc}\left[\mathrm{CO}_{3}{ }^{2-}\right]\right)$ :

$$
\mathrm{xc}\left[\mathrm{CO}_{3}{ }^{2-}\right]=\left[\mathrm{CO}_{3}{ }^{2-}\right]_{\text {is }}-\left[\mathrm{CO}_{3}{ }^{2-}\right]_{\operatorname{sat}(\Omega \mathrm{A}=1)}(3) .
$$

Positive (negative) ${ }_{\mathrm{xc}}\left[\mathrm{CO}_{3}{ }^{2-}\right]$ indicates that water is supersaturated (undersaturated) with respect to aragonite. The ${ }_{\mathrm{xc}}\left[\mathrm{CO}_{3}{ }^{2-}\right]$ is an absolute measure of the tendency for the aragonite mineral to precipitate/dissolve ${ }^{33}$ so that, contrary to the widely used $\Omega_{\mathrm{A}}$ that is a ratio, it is founded to compute ${ }_{x c}\left[\mathrm{CO}_{3}{ }^{2-}\right]$ transport. In addition, changes in ${ }_{x c}\left[\mathrm{CO}_{3}{ }^{2-}\right]$ are directly 
comparable with changes in $\left[\mathrm{CO}_{3}{ }^{2-}\right]$ is, which in this study was computed from total alkalinity $\left(\mathrm{A}_{\mathrm{T}}\right)$ and total dissolved inorganic carbon $\left(\mathrm{C}_{\mathrm{T}}\right)$. The acid dissociation constants of Dickson and Millero ${ }^{34}$ and aragonite solubilities of Mucci $^{35}$ were selected to determine ${ }_{x c}\left[\mathrm{CO}_{3}{ }^{2-}\right]$ and other derived variables of the marine $\mathrm{CO}_{2}$ system using the $\mathrm{CO} 2 \mathrm{SYS}$ toolbox ${ }^{36,37}$.

\section{Present, natural and projected values of ${ }_{\mathrm{xc}}\left[\mathrm{CO}_{3}{ }^{2-}\right]$ and $\left[\mathrm{H}^{+}\right]$}

Present ${ }_{x c}\left[\mathrm{CO}_{3}{ }^{2-}\right]$ and $\left[\mathrm{H}^{+}\right]$were determined using measured data of the marine $\mathrm{CO}_{2}$ system $\left(\mathrm{AT}_{\mathrm{T}}, \mathrm{C}_{\mathrm{T}}\right.$ and $\left.\mathrm{pH}\right)$, temperature, salinity and pressure. We separated anthropogenic from natural ${ }_{x c}\left[\mathrm{CO}_{3}{ }^{2-}\right]$ and $\left[\mathrm{H}^{+}\right]$by assuming that the natural component corresponds to an ocean in equilibrium with a pre-industrial atmosphere, whereas the remaining is anthropogenic. Along the Ovide section, we determined the anthropogenic $\mathrm{CO}_{2}\left(\mathrm{C}_{\text {ant }}\right)$ using the backcalculation $\varphi \mathrm{C}_{\mathrm{T}}{ }^{\mathrm{o}}$ method ${ }^{19,38,39}$ with an overall uncertainty of $\pm 5.2 \mu \mathrm{mol} \mathrm{kg}{ }^{-1}$. For the Nordic Sills, the parameters of the marine $\mathrm{CO}_{2}$ system were taken from Jeansson et al. ${ }^{18}$. Natural $\mathrm{C}_{\mathrm{T}}$ was determined by subtracting the $\mathrm{C}_{\mathrm{ant}}$ to the measured $\mathrm{C}_{\mathrm{T}}$. Natural $\mathrm{xc}\left[\mathrm{CO}_{3}{ }^{2-}\right]$ and $\left[\mathrm{H}^{+}\right]$were determined using measured $\mathrm{A}_{\mathrm{T}}$ and natural $\mathrm{C}_{\mathrm{T}}$ and the equations of the marine $\mathrm{CO}_{2}$ system using CO2SYS toolbox ${ }^{36,37}$.

The Shared Socio-Economic Pathways, SSP ${ }^{4}$ (Extended Data Fig. 2), indicate that the doubling of the present atmospheric $\mathrm{C}_{\text {ant }}$ of $100-120 \mathrm{ppm}$, i.e. atmospheric $\mathrm{CO}_{2}$ of $480-520$ ppm (200-240 ppm over pre-industrial values), would lead to a $2^{\circ} \mathrm{C}$-warming scenario. The ${ }_{x c}\left[\mathrm{CO}_{3}{ }^{2-}\right]$ and $\left[\mathrm{H}^{+}\right]$for this scenario were calculated by doubling the present atmospheric $\mathrm{C}_{\text {ant. }}$. The comparison of the observed changes in $\mathrm{C}_{\mathrm{T}}$ and chlorofluorocarbons with those predicted from an eddy-permitting ocean circulation model confirmed that $\mathrm{C}_{\text {ant }}$ changes follow the transient steady state (TSS) approximation ${ }^{22,23,40}$. This means that $\mathrm{C}_{\text {ant }}$ increases over time through the whole water column proportionally to the increase in $\mathrm{C}_{\text {ant }}$ in the surface mixed layer. Hence, we estimated the seawater $\mathrm{C}_{\mathrm{ant}}$ for the doubling of atmospheric $\mathrm{C}_{\mathrm{ant}}$ from the present-day seawater $\mathrm{C}_{\mathrm{ant}}$ considering that the change in the seawater surface $\mathrm{C}_{\text {ant }}$ follows the change in atmospheric $\mathrm{CO}_{2}$. The seawater $\mathrm{C}_{\text {ant }}$ for this scenario was estimated to be $72 \pm 3 \%$ higher than the present seawater $C_{\text {ant }}$ (Extended Data Fig. 4), based on a large range of temperatures $\left(0-20^{\circ} \mathrm{C}\right)$ and a $\mathrm{CO}_{2}$ air-sea disequilibrium ${ }^{41}$ of $10 \pm 5 \%$. The ${ }_{\mathrm{xc}}\left[\mathrm{CO}_{3}{ }^{2-}\right]$ and $\left[\mathrm{H}^{+}\right]$for the doubling of atmospheric $\mathrm{C}_{\mathrm{ant}}$ scenario were determined by 
adding the 0.72 times the present seawater $\mathrm{C}_{\text {ant }}$ to the measured $\mathrm{C}_{\mathrm{T}}$ and using measured $\mathrm{A}_{\mathrm{T}}$ and temperature. $\left[\mathrm{H}^{+}\right]$is given in pmol kg${ }^{-1}$ as the $\log ^{-1}$ of $\mathrm{pH}_{\mathrm{T}}$ (in total scale). The uncertainty range for the ASH for the doubling of atmospheric $\mathrm{C}_{\text {ant }}$ scenario (milky area in Fig. 1c) was determined considering an atmospheric $\mathrm{CO}_{2}$ concentration of 480-520 ppm.

\section{Present, natural and projected carbonate ion excess at cold-water coral (CWC) locations}

The stony coral database was derived from records compiled by Rogers et al. ${ }^{42}$, HallSpencer et al. ${ }^{43}$ and a database of $L$. pertusa records compiled by the United Nations Environment Programme - World Conservation Monitoring Centre (UNEP-WCMC) based in the CWC Global distribution ${ }^{44}$. From the obtained 6,553 CWC records, we removed those without geo-referenced coordinates or depth data, those shallower than 1,000 m, and those characterized as dead or fossil, obtaining $548 \mathrm{CWC}$ records (Fig. 1a and Extended Data Table 1). To determine the physicochemical characteristics of the seawater surrounding those $548 \mathrm{CWC}$ locations, we used a multiparametric interpolation method (Water Mass Properties [WMP] interpolation method) ${ }^{45}$ to interpolate in situ temperature, salinity, $\mathrm{A}_{\mathrm{T}}$ and $\mathrm{C}_{\mathrm{T}}$ from the quality controlled GLODAPv2 database ${ }^{12,13}$. The WMP method improves the estimates obtained from purely spatial interpolation by applying a weighting process using the distances in conservative parameters and using a helper database with higher resolution (World Ocean Atlas ${ }^{46-49}$ ) for these conservative parameters. The $\mathrm{C}_{\mathrm{ant}}$ at those $548 \mathrm{CWC}$ locations for 2010 was interpolated from the $\mathrm{C}_{\text {ant }}$ given by Khatiwala et al. ${ }^{50}$. Following the same procedure as that described above, the present, natural and projected ${ }_{\mathrm{xc}}\left[\mathrm{CO}_{3}{ }^{2-}\right]$ for a doubling of atmospheric $\mathrm{C}_{\text {ant }}$ were determined. The results are summarized in Extended Data Table 1.

\section{Circulation of carbonate ions and anthropogenic $\mathrm{CO}_{2}$ in the Subpolar North Atlantic}

The absolute geostrophic velocity fields orthogonal to the Ovide sections were determined using an inverse model constrained by subsurface acoustic Doppler current profiler measurements and an overall mass conservation constraint ${ }^{17,51-53}$. The resulting absolute velocity fields are consistent with independent altimetry measurements ${ }^{52}$ and estimates of the western boundary current transport ${ }^{53}$ at the time of the Ovide cruises. The velocity fields are representative of the month of the cruise and the seasonal variability was removed 
310 as explained in Pérez et al. ${ }^{19}$. The mean velocity field of the Ovide section during 2002-

3112016 is shown in Extended Data Fig. 5. Transports of $x c\left[\mathrm{CO}_{3}{ }^{2-}\right],\left[\mathrm{H}^{+}\right], \mathrm{C}_{\text {ant }}$ and $\left[\mathrm{CO}_{3}{ }^{2-}\right]$ were

312 calculated using the velocity field, density and the tracer concentration $\left(x c\left[\mathrm{CO}_{3}{ }^{2-}\right],\left[\mathrm{H}^{+}\right], \mathrm{C}_{\mathrm{ant}}\right.$ 313 or $\left.\left[\mathrm{CO}_{3}{ }^{2-}\right]\right)$ through Eq. (4):

$$
\text { Transport }_{\text {Tracer }}=\Sigma[\text { Tracer }] * \text { density }_{\text {is }} * \text { velocity } * \text { area }
$$

315 The transports of seawater, $x c\left[\mathrm{CO}_{3}{ }^{2-}\right],\left[\mathrm{H}^{+}\right], \mathrm{C}_{\text {ant }}$ and $\left[\mathrm{CO}_{3}{ }^{2-}\right]$ are summarize in Extended

316 Data Table 2, Fig. 3 and Extended Data Fig. 6. The transports of ${ }_{x c}\left[\mathrm{CO}_{3}{ }^{2-}\right]$ and $\left[\mathrm{H}^{+}\right]$are also 317 given for present, pre-industrial (natural) and doubling of atmospheric $\mathrm{C}_{\text {ant }}$ scenario.

318 Uncertainties in the AMOC, and in the transport of $\mathrm{xc}_{\mathrm{xc}}\left[\mathrm{CO}_{3}{ }^{2-}\right]$ and $\left[\mathrm{H}^{+}\right]$trough the Ovide 319 section were calculated as the standard error of the mean of the eight occupations of the 320 Ovide section during $2002-2016$ (s.e. $=\mathrm{std} / \sqrt{8}$ ). Transport at the sills was derived from 321 Jeansson et al. ${ }^{18}$ and Pérez et al. ${ }^{19}$ and results are summarized in Extended Data Table 3. 


\section{ADDITIONAL REFERENCES:}

30. Fabry, V. J., Seibel, B. A., Feely, R. A. \& Orr, J. C. Impacts of ocean acidification on marine fauna and ecosystem processes. ICES J Mar Sci 65, 414-432 (2008).

31. Fabry, V. O. ., McClintock, J. B., Mathis, J. T. \& Grebmeier, J. M. Ocean acidification at high latitudes: the bellwether. Oceanography 22, 160-171 (2009).

32. Millero, F. J., Feistel, R., Wright, D. G. \& McDougall, T. J. The composition of Standard Seawater and the definition of the Reference-Composition Salinity Scale. Deep Sea Res. Part Oceanogr. Res. Pap. 55, 50-72 (2008).

33. Subhas, A. V. et al. A novel determination of calcite dissolution kinetics in seawater. Geochim. Cosmochim. Acta 170, 51-68 (2015).

34. Dickson, A. \& Millero, F. A comparison of the equilibrium constants for the dissociation of carbonic acid in seawater media. Deep-Sea Res. 34, 1733-1743 (1987).

35. Mucci, A. The solubility of calcite and aragonite in seawater at various salinities, temperatures, and one atmosphere total pressure. Am. J. Sci. 283, 780-799 (1983).

36. Lewis, E., Wallace, D. \& Allison, L. Program developed for CO2 system calculations. (ORNL/CDIAC-105, Carbon Dioxide Information Analysis Center, Oak Ridge National Laboratory, U.S. Department of Energy, Oak Ridge, Tennessee, 1998).

37. van Heuven, S., Pierrot, D., Lewis, E. \& Wallace, D. MATLAB Program developed for CO2 system calculations. (ORNL/CDIAC-105b, Carbon Dioxide Information Analysis Center, Oak Ridge National Laboratory, U.S. Department of Energy, Oak Ridge, Tennessee, 2009).

38. Pérez, F. F. et al. Temporal variability of the anthropogenic $\mathrm{CO} 2$ storage in the Irminger Sea. Biogeosciences 5, 1669-1679 (2008).

39. Vázquez-Rodríguez, M. et al. Anthropogenic carbon distributions in the Atlantic Ocean: data-based estimates from the Arctic to the Antarctic. Biogeosciences 6, 439451 (2009).

40. Tanhua, T., Körtzinger, A., Friis, K., Waugh, D. W. \& Wallace, D. W. R. An estimate of anthropogenic $\mathrm{CO} 2$ inventory from decadal changes in oceanic carbon content. Proc. Natl. Acad. Sci. 104, 3037 (2007). 
41. Matsumoto, K. \& Gruber, N. How accurate is the estimation of anthropogenic carbon in the ocean? An evaluation of the $\Delta C^{*}$ method. Glob. Biogeochem. Cycles 19, GB3014 (2005).

42. Rogers, A. D., Baco, A., Griffiths, H., Hart, T. \& Hall-Spencer, J. M. Corals on Seamounts. in Seamounts: Ecology, Fisheries \& Conservation (eds. Pitcher, T. J. et al.) 141-169 (Blackwell Publishing Ltd, 2007).

43. Hall-Spencer, J., Rogers, A., Davies, J. \& Foggo, A. Deep-sea coral distribution on seamounts, oceanic islands, and continental slopes in the Northeast Atlantic. Bull. Mar. Sci. 81, 135-146 (2007).

44. Freiwald, A. et al. Global distribution of cold-water corals (version 3.0). Second update to the dataset in Freiwald et al. (2004) by UNEP-WCMC, in collaboration with Andre Freiwald and John Guinotte. Cambridge (UK): UNEP World Conservation Monitoring Centre. URL: http://data.unep-wcmc.org/datasets/3. (2017).

45. Velo, A. et al. A multiparametric method of interpolation using WOA05 applied to anthropogenic CO2 in the Atlantic. Sci. Mar. 74, 21-32 (2010).

46. Locarnini, R. A. et al. World Ocean Atlas 2013, Volume 1: Temperature. NOAA Atlas NESDIS 73, 40 (2013).

47. Zweng, M. . et al. World Ocean Atlas 2013, Volume 2: Salinity. NOAA Atlas NESDIS 74, 39 (2013).

48. Garcia, H. E. et al. World Ocean Atlas 2013, Volume 3: Dissolved Oxygen, Apparent Oxygen Utilization, and Oxygen Saturation. NOAA Atlas NESDIS 75, 27 (2014).

49. Garcia, H. E. et al. World Ocean Atlas 2013, Volume 4: Dissolved Inorganic Nutrients (phosphate, nitrate, silicate). NOAA Atlas NESDIS 76, 25 (2014).

50. Khatiwala, S., Primeau, F. \& Hall, T. Reconstruction of the history of anthropogenic $\mathrm{CO}_{2}$ concentrations in the ocean. Nature 462, 346-349 (2009).

51. Lherminier, P. et al. The Atlantic Meridional Overturning Circulation and the subpolar gyre observed at the A25-OVIDE section in June 2002 and 2004. Deep Sea Res. Part Oceanogr. Res. Pap. 57, 1374-1391 (2010).

52. Gourcuff, C., Lherminier, P., Mercier, H. \& Le Traon, P. Y. Altimetry Combined with Hydrography for Ocean Transport Estimation. J. Atmospheric Ocean. Technol. 28, 1324-1337 (2011). 
53. Daniault, N., Lherminier, P. \& Mercier, H. Circulation and Transport at the Southeast Tip of Greenland. J. Phys. Oceanogr. 41, 437-457 (2011).

54. Kriegler, E. et al. Fossil-fueled development (SSP5): An energy and resource intensive scenario for the 21 st century. Global Environmental Change (2017).

doi:http://dx.doi.org/10.1016/j.gloenvcha.2016.05.015 

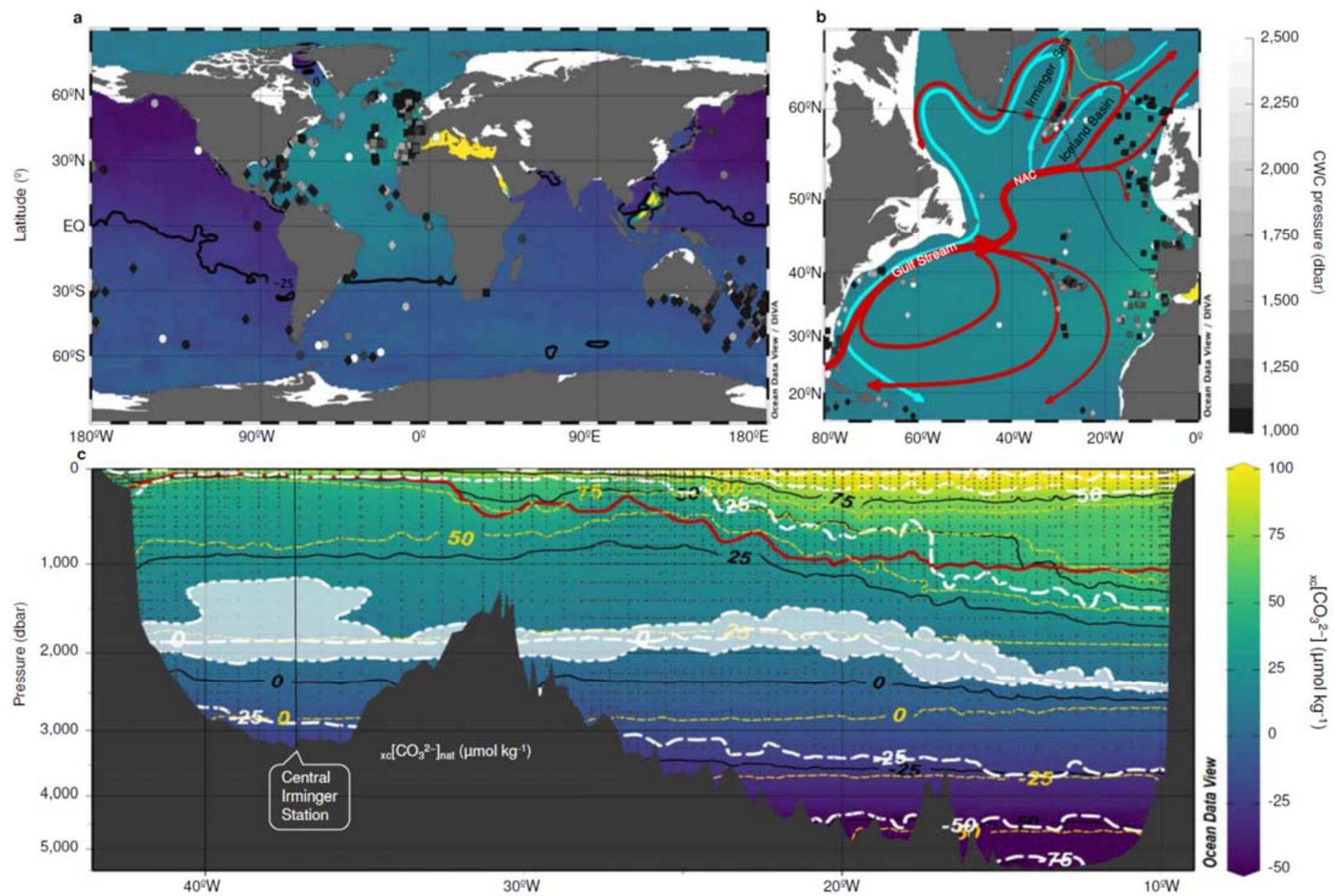

Figure 1 | Aragonite saturation and cold-water coral distribution. (a) $x\left[\mathrm{CO}_{3}{ }^{2-}\right]$ at 1,500 $\mathrm{m}$ (lower-right colorbar). Circles, diamonds and squares represent CWC locations where ${ }_{x c}\left[\mathrm{CO}_{3}{ }^{2-}\right]<0,0<{ }_{x c}\left[\mathrm{CO}_{3}{ }^{2-}\right]<25$, and $x_{x c}\left[\mathrm{CO}_{3}{ }^{2-}\right]>25 \mu \mathrm{mol} \mathrm{kg}{ }^{-1}$, respectively. Depths are graycoded (upper-right colorbar). (b) Central Irminger Station (red star), Ovide section (dotted line) and circulation of upper (red) and lower (blue) AMOC limbs. (c) $x_{\mathrm{c}}\left[\mathrm{CO}_{3}{ }^{2-}\right]$ observed 398 atmospheric $\mathrm{C}_{\text {ant }}$ (dashed-white line) along the Ovide section. The milky area is uncertainty 399 for aragonite saturation horizon $\left(\mathrm{xc}_{\mathrm{c}}\left[\mathrm{CO}_{3}{ }^{2-}\right]=0\right)$. The red line separates the upper and lower 400 AMOC limbs. Dots represent samples. 

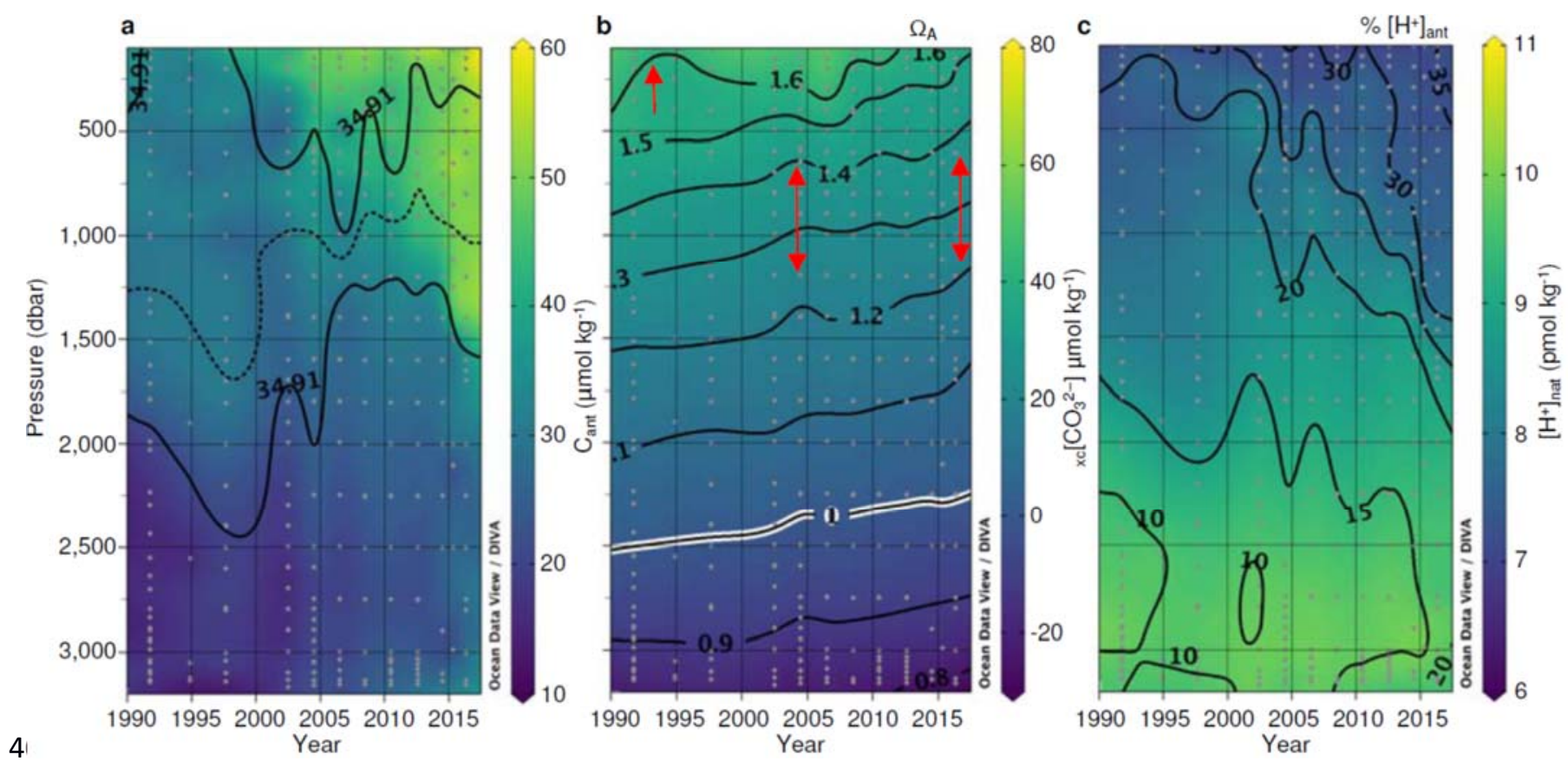

403 Figure 2 | Ocean Acidification at the Central Irminger Station. (a) Time evolution from

4041991 to 2016 of anthropogenic $\mathrm{CO}_{2}\left(\mathrm{C}_{\mathrm{ant}}\right.$, colorbar), the isohaline of 34.91 (continuous

405 black lines) and salinity minimum (dotted black line). (b) Time evolution from 1991 to

4062016 of aragonite saturation $\left(\Omega_{\mathrm{A}}\right.$, contours) and excess of carbonate ion concentration over

407 aragonite saturation $\left(\mathrm{xc}\left[\mathrm{CO}_{3}{ }^{2-}\right]\right.$, colorbar). Arrows indicate the effects of deep convection

408 events. (c) Time evolution from 1991 to 2016 of natural (pre-industrial) hydrogenion

409 concentration $\left(\left[\mathrm{H}^{+}\right]\right.$nat, colorbar, in pmol kg$\left.{ }^{-1}\right)$ and percentage of change in $\left[\mathrm{H}^{+}\right]$due to

410 anthropogenic emissions $\left(\%\left[\mathrm{H}^{+}\right]\right.$ant, contours $)$. 


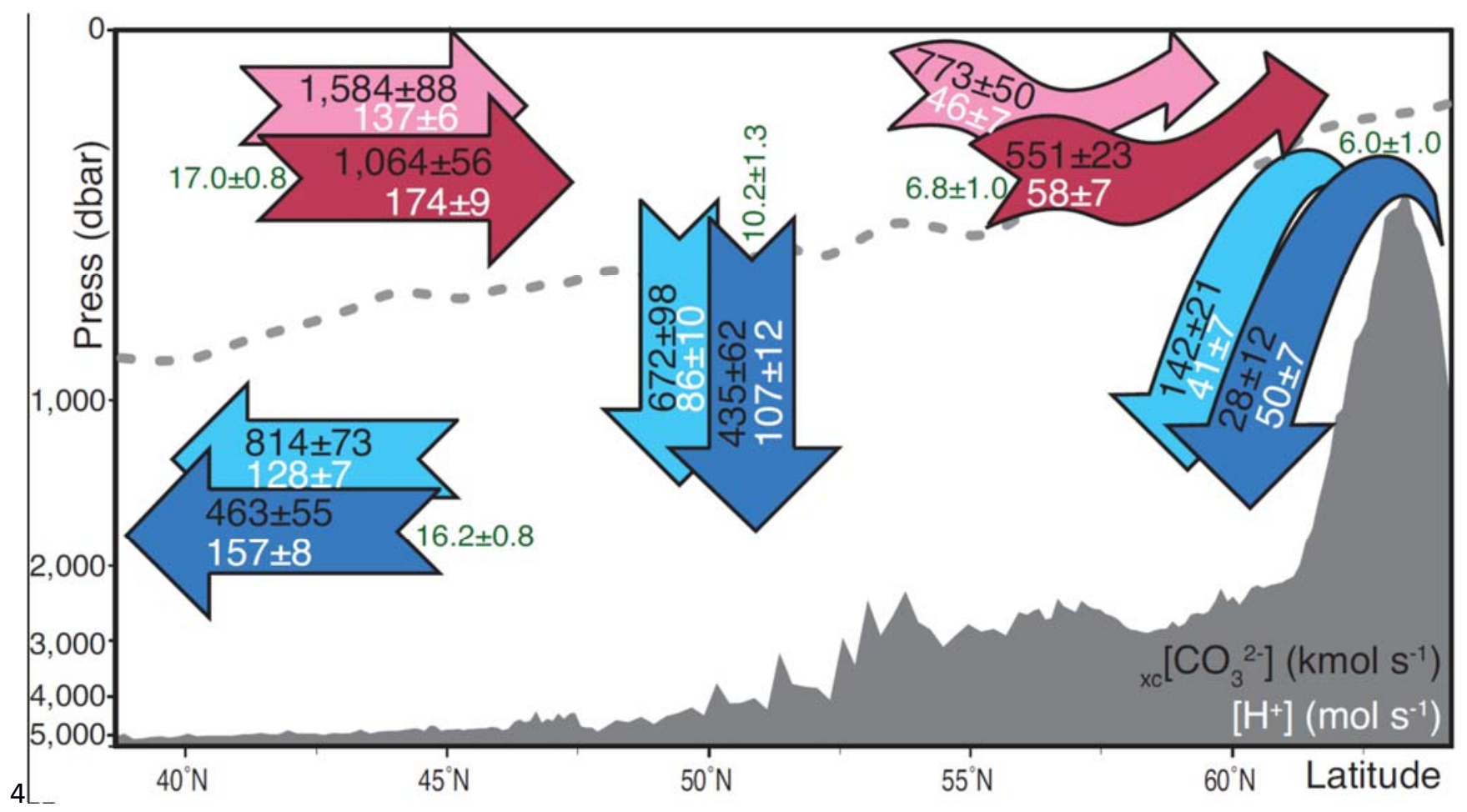

413 Figure 3 | Circulation of the excess of $\left[\mathrm{CO}_{3}{ }^{2-}\right]$ over aragonite saturation and $\left[\mathrm{H}^{+}\right]$in the

414 Subpolar North Atlantic. Mean transports for 2002-2016 between the Ovide section and

415 the Nordic Sills of seawater (green values, in Sv), and natural (pre-industrial; light coloured

416 arrows) and observed (dark coloured arrows) excess of [ $\left.\mathrm{CO}_{3}{ }^{2-}\right]$ over aragonite saturation

$417\left(\mathrm{xc}\left[\mathrm{CO}_{3}{ }^{2-}\right]\right.$, in $\mathrm{kmol} \mathrm{s}^{-1}$, black values $)$ and hydrogenions $\left(\left[\mathrm{H}^{+}\right]\right.$, in $\mathrm{mol} \mathrm{s}^{-1}$, white values $)$.

418 Uncertainties are the errors in the mean transports across the eight occupations of the Ovide

419 line $(\operatorname{std} / \sqrt{8})$. The grey dotted line represents the limit between the upper and lower limbs

420 of the AMOC. 
422 Extended Data Legends

423 Extended Data Table 1 | Aragonite saturation at cold-water coral locations. Number

424 (N) of locations of cold-water corals (CWC) in the Global and North Atlantic (NA) Oceans

425 below 1,000 and $1,500 \mathrm{~m}$, along with the percentage of the CWC located below the

426 aragonite saturation horizon (ASH) for natural (pre-industrial; subscript 'nat'), present

427 (subscript '2010') and for the doubling of atmospheric Cant scenario (subscript ' $2 x$ '). The

428 average natural, measured (GLODAPv2) ${ }^{12,13}$ and for the doubling of atmospheric $\mathrm{C}_{\text {ant }}$

429 scenario excess of carbonate ion concentration over aragonite saturation $\left(\mathrm{xc}_{\mathrm{c}}\left[\mathrm{CO}_{3}{ }^{2-}\right]\right.$, in $\mu \mathrm{mol}$

$430 \mathrm{~kg}^{-1}$ ) are also shown.

\begin{tabular}{|c|c|c|c|c|c|c|c|c|}
\hline Depth (m) & Ocean & $\mathrm{N}$ & $<\mathrm{ASH}_{\text {nat }}$ & $<\mathrm{ASH}_{210}$ & $<\mathrm{ASH}_{2 \mathrm{x}}$ & $\mathrm{xc}\left[\mathrm{CO}^{2-}\right]_{\text {nat }}$ & $\mathrm{xc}\left[\mathrm{CO}^{2-}\right]_{2010}$ & $\mathrm{xc}\left[\mathrm{CO}^{2-}\right]_{2}$ \\
\hline \multirow{2}{*}{$\geq 1000$} & Global & 548 & $12 \%$ & $17 \%$ & $47 \%$ & 29 & 14.5 & 4 \\
\hline & NA & $335(61 \%)$ & $1 \%$ & $2 \%$ & $32 \%$ & 43 & 24.5 & 10.5 \\
\hline \multirow{2}{*}{$\geq 1500$} & Global & 176 & $20 \%$ & $22 \%$ & $74 \%$ & 22 & 6.7 & -8 \\
\hline & NA & $139(78 \%)$ & $2 \%$ & $4 \%$ & $70 \%$ & 34 & 15 & -3 \\
\hline
\end{tabular}

432

433 
434 Extended Data Table 2 | Transports of seawater, ${ }_{x c}\left[\mathrm{CO}_{3}{ }^{2-}\right],\left[\mathrm{H}^{+}\right], \mathrm{C}_{\text {ant }}$ and $\left[\mathrm{CO}_{3}{ }^{2-}\right]$.

435 Transport of volume (in Sv; $\left.1 \mathrm{~Sv}=10^{6} \mathrm{~m}^{3} \mathrm{~s}^{-1}\right)$, anthropogenic $\mathrm{CO}_{2}\left(\mathrm{C}_{\text {ant }}\right.$, in $\left.\mathrm{kmol} \mathrm{s}^{-1}\right)$,

436 carbonate ion concentration $\left(\left[\mathrm{CO}_{3}{ }^{2-}\right]\right.$, in $\left.\mathrm{kmol} \mathrm{s}^{-1}\right)$, excess of carbonate ion concentration

437 over aragonite saturation $\left(x c\left[\mathrm{CO}_{3}{ }^{2-}\right]\right.$, in $\left.\mathrm{kmol} \mathrm{s}^{-1}\right)$, and hydrogen ion concentration $\left(\left[\mathrm{H}^{+}\right]\right.$, in

$438 \mathrm{pmol} \mathrm{s}^{-1}$ ) across the Ovide section during 2002-2016 in the upper and lower limbs of the

439 Atlantic Meridional Overturning Circulation (AMOC). Values of the natural (pre-

440 industrial) component (subscript 'nat') and for the doubling of atmospheric $\mathrm{C}_{\text {ant }}$ scenario

441 (subscript ' $2 \mathrm{x}$ ') are also shown. Uncertainties $\left(E r r_{-} \mathrm{x}\right)$ are estimated as the error of the mean

442 of the eight occupations of the Ovide section $(\operatorname{std} / \sqrt{8})$. Positive (negative) transports

443 indicate northward (southward) transport. The velocity-weighted averaged values of

$444 x c\left[\mathrm{CO}_{3}{ }^{2-}\right]$ for pre-industrial, present (2002-2016) and for the doubling of atmospheric $\mathrm{C}_{\text {ant }}$

445 scenario are also given.

\begin{tabular}{|c|c|c|c|c|c|c|c|c|c|c|}
\hline Year & Vol (Sv) & $\begin{array}{c}\mathrm{C}_{\text {ant }} \\
\left(\mathrm{kmol} \cdot \mathrm{s}^{-1}\right)\end{array}$ & $\begin{array}{c}{\left[\mathrm{CO3}^{2-}\right]} \\
\left(\mathrm{kmol} \cdot \mathrm{s}^{-1}\right)\end{array}$ & $\begin{array}{l}{\left[\mathrm{CO3}^{2}{ }^{-}\right]_{\text {nat }}} \\
\left(\mathrm{kmol} \cdot \mathrm{s}^{-1}\right)\end{array}$ & $\begin{array}{l}{ }_{x c}\left[\mathrm{CO}^{2} \cdot\right] \\
\left(\mathrm{kmol} \cdot \mathrm{s}^{-1}\right)\end{array}$ & $\begin{array}{c}{ }_{x c}\left[\mathrm{CO}^{2-}\right]_{\text {nat }} \\
\left(\mathrm{kmol} \cdot \mathrm{s}^{-1}\right)\end{array}$ & $\begin{array}{l}{ }_{x c}\left[\mathrm{COO}^{2-}\right]_{2 x} \\
\left(\mathrm{kmol} \cdot \mathrm{s}^{-1}\right)\end{array}$ & $\begin{array}{c}{\left[\mathrm{H}^{+}\right]} \\
\left(\mathrm{pmol} \cdot \mathrm{s}^{-1}\right)\end{array}$ & $\begin{array}{c}{ }^{\left[\mathrm{H}^{+}\right]_{\text {nat }}} \\
\left(\mathrm{pmol}^{\left.-\mathrm{s}^{-1}\right)}\right.\end{array}$ & $\begin{array}{c}{\left[\mathrm{H}^{+}\right]_{2 \mathrm{x}}} \\
\left(\mathrm{pmol} \cdot \mathrm{s}^{-1}\right)\end{array}$ \\
\hline \multicolumn{11}{|c|}{ AMOC upper limb } \\
\hline 2002 & 17.3 & 761 & 2,322 & 2,784 & 1,058 & 1,520 & 737 & 177 & 144 & 209 \\
\hline 2004 & 17.15 & 820 & 2,409 & 2,910 & 1,172 & 1,673 & 823 & 172 & 138 & 205 \\
\hline 2006 & 11.97 & 528 & 1,596 & 1,917 & 743 & 1,064 & 520 & 119 & 97 & 141 \\
\hline 2008 & 17.14 & 886 & 2,412 & 2,954 & 1,173 & 1,716 & 795 & 171 & 135 & 206 \\
\hline 2010 & 18.03 & 919 & 2,477 & 3,037 & 1,166 & 1,727 & 776 & 187 & 148 & 225 \\
\hline 2012 & 16.51 & 819 & 2,116 & 2,609 & 922 & 1,415 & 578 & 172 & 135 & 208 \\
\hline 2014 & 18.75 & 1,048 & 2,563 & 3,200 & 1,199 & 1,837 & 755 & 189 & 147 & 230 \\
\hline 2016 & 19.04 & 1,068 & 2,468 & 3,114 & 1,078 & 1,724 & 628 & 201 & 154 & 247 \\
\hline Avg. & 17 & 856 & 2,295 & 2,816 & 1,064 & 1,584 & 701 & 174 & 137 & 209 \\
\hline Err_x & 0.78 & 61 & 110.3 & 144.2 & 56 & 88 & 39 & 9 & 6 & 11 \\
\hline \multicolumn{5}{|c|}{ Velocity-weighted averaged ${ }_{x c}\left[\mathrm{CO}^{2 \cdot}\right]$} & $61 \pm 2$ & $90 \pm 2$ & $40 \pm 1.4$ & & & \\
\hline \multicolumn{11}{|c|}{ AMOC lower limb } \\
\hline 2002 & -16.5 & -548 & $-1,920$ & $-2,240$ & -640 & -960 & -417 & -151 & -127 & -175 \\
\hline 2004 & -16.3 & -547 & $-1,812$ & $-2,128$ & -454 & -770 & -233 & -156 & -130 & -181 \\
\hline 2006 & -11.2 & -343 & $-1,294$ & $-1,495$ & -357 & -557 & -218 & -106 & -90 & -121 \\
\hline 2008 & -16.3 & -694 & $-1,899$ & $-2,305$ & -680 & $-1,087$ & -397 & -150 & -120 & -180 \\
\hline 2010 & -17.2 & -567 & $-1,913$ & $-2,239$ & -288 & -614 & -60 & -175 & -147 & -202 \\
\hline 2012 & -15.7 & -646 & $-1,769$ & $-2,144$ & -524 & -899 & -263 & -151 & -121 & -181 \\
\hline 2014 & -17.9 & -636 & $-1,899$ & $-2,262$ & -259 & -622 & -6 & -184 & -151 & -215 \\
\hline 2016 & -18.2 & -882 & $-1,957$ & $-2,465$ & -500 & $-1,007$ & -146 & -184 & -140 & -226 \\
\hline Avg. & -16.2 & -608 & $-1,808$ & $-2,160$ & -463 & -814 & -217 & -157 & -128 & -185 \\
\hline Err_x & 0.78 & 43 & 84.8 & 106 & 55 & 73 & 46 & 8 & 7 & 10 \\
\hline \multicolumn{5}{|c|}{ Velocity-weighted averaged ${ }_{x c}\left[\mathrm{CO}^{2-}\right]$} & $28 \pm 3$ & $49 \pm 4$ & $13.6 \pm 2.7$ & & & \\
\hline
\end{tabular}


448 Extended Data Table 3 | Transports at the Nordic Sills. Volume transport (Vol., in Sv), 449 potential temperature (Tpot, in ${ }^{\circ} \mathrm{C}$ ), salinity, total dissolved inorganic carbon $\left(\mathrm{C}_{\mathrm{T}}\right.$, in $\mu \mathrm{mol}$ $\left.450 \mathrm{~kg}^{-1}\right)$, total alkalinity $\left(\mathrm{A}_{\mathrm{T}}\right.$, in $\left.\mu \mathrm{mol} \mathrm{kg}{ }^{-1}\right)$, anthropogenic $\mathrm{CO}_{2}\left(\mathrm{C}_{\text {ant }}\right.$, in $\left.\mu \mathrm{mol} \mathrm{kg}{ }^{-1}\right)$, carbonate 451 ion concentration $\left(\left[\mathrm{CO}_{3}{ }^{2-}\right]\right.$, in $\left.\mu \mathrm{mol} \mathrm{kg}{ }^{-1}\right)$, excess of carbonate ion concentration over 452 aragonite saturation $\left({ }_{x c}\left[\mathrm{CO}_{3}{ }^{2-}\right]\right.$, in $\left.\mu \mathrm{mol} \mathrm{kg}{ }^{-1}\right)$, and hydrogen ion concentration $\left(\left[\mathrm{H}^{+}\right]\right.$, in $453 \mathrm{pmol} \mathrm{kg}{ }^{-1}$ ) through the Nordic Sills in the upper and lower limbs of the AMOC, separated 454 by isopycnal $1,027.8 \mathrm{~kg} \mathrm{~m}^{-3}$. Values for the natural (pre-industrial) component (subscript 455 'nat') are also shown. Salinity and marine $\mathrm{CO}_{2}$ system data $\left(\mathrm{C}_{\mathrm{T}}\right.$ and $\left.\mathrm{AT}_{\mathrm{T}}\right)$ taken from 456 Jeansson et al. ${ }^{17}$. Volume transports taken from Pérez et al. ${ }^{19}$. AW, OW and PW stand for 457 Atlantic, Overflow and Polar Waters, respectively; and the subscripts stand for: Faroes458 Shetland, between Faroes and Shetland islands; Iceland-Faroe, across the Iceland-Faroe 459 Ridge; W-Iceland, West of Iceland; and Denmark Strait, through Denmark Strait.

460 Uncertainties of volume transport, salinity, $\mathrm{C}_{\mathrm{T}}, \mathrm{C}_{\mathrm{ant}}$ and $\mathrm{A}_{\mathrm{T}}$ taken from Jeansson et al. ${ }^{18}$. 461 The uncertainties of $\mathrm{C}_{\mathrm{T}}$ and $\mathrm{A}_{\mathrm{T}}$ were propagated to $\left[\mathrm{CO}^{2-}\right]$ and $\left[\mathrm{H}^{+}\right]$by a Monte-Carlo 462 approach using the marine $\mathrm{CO}_{2}$ system equations.

\begin{tabular}{|c|c|c|c|c|c|c|c|c|c|c|c|c|}
\hline Layer & Vol (Sv) & Tpot $\left({ }^{\circ} \mathrm{C}\right)$ & Salinity & $\underset{\left(\mu \mathrm{mol} \cdot \mathrm{kg}^{-1}\right)}{\mathrm{C}_{\mathrm{T}}}$ & $\begin{array}{c}A_{\mathrm{T}} \\
\left(\mu \mathrm{mol} \cdot \mathrm{kg}^{-1}\right)\end{array}$ & $\underset{\left(\mu \mathrm{mol} \cdot \mathrm{kg}^{-1}\right)}{\mathrm{C}_{\text {ant }}}$ & $\underset{\left(\mu \mathrm{mol} \cdot \mathrm{kg}^{-1}\right)}{\left[\mathrm{CO}^{2} \cdot\right]}$ & $\begin{array}{l}{\left[\mathrm{CO}^{2}-\right]_{\text {nat }}} \\
\left(\mu \mathrm{mol} \cdot \mathrm{kg}^{-1}\right)\end{array}$ & $\begin{array}{c}\left.{ }_{(\mu \mathrm{coO}}{ }^{2-}\right] \\
\left(\mu \mathrm{mol} \cdot \mathrm{kg}^{-1}\right)\end{array}$ & $\begin{array}{l}{ }_{x}\left[\mathrm{COO}^{2}-\right]_{\text {nat }} \\
\left(\mu \mathrm{mol} \cdot \mathrm{kg}^{-1}\right)\end{array}$ & $\begin{array}{c}{\left[\mathrm{H}^{+}\right]} \\
\left(\mathrm{pmol} \cdot \mathrm{kg}^{-1}\right)\end{array}$ & $\begin{array}{c}{\left[\mathrm{H}^{+}\right]_{\text {nat }}} \\
\left(\mathrm{pmol}^{\left.-\mathrm{kg}^{-1}\right)}\right.\end{array}$ \\
\hline \multicolumn{13}{|c|}{ AMOC upper limb (Density <27.8) } \\
\hline $\mathrm{AW}_{\text {Faroes-Shetland }}$ & $3.9 \pm 0.5$ & $9.18 \pm 0.55$ & $35.27 \pm 0.11$ & $2,121 \pm 20$ & $2,325 \pm 7$ & $50 \pm 3$ & $146 \pm 8$ & $176 \pm 10$ & $76 \pm 8$ & $107 \pm 10$ & $8.0 \pm 0.9$ & $6.4 \pm 1.0$ \\
\hline $\mathrm{AW}_{\text {Iceland-Faroe }}$ & $3.9 \pm 0.5$ & $8.10 \pm 0.30$ & $35.18 \pm 0.06$ & $2,127 \pm 22$ & $2,323 \pm 6$ & $47 \pm 3$ & $140 \pm 10$ & $169 \pm 12$ & $70 \pm 10$ & $99 \pm 12$ & $8.0 \pm 1.1$ & $6.4 \pm 1.3$ \\
\hline $\mathrm{AW}_{\mathrm{W} \text {-iceland }}$ & $0.8 \pm 0.16$ & $6.00 \pm 0.15$ & $35.06 \pm 0.03$ & $2,138 \pm 3$ & $2,309 \pm 2$ & $48 \pm 2$ & $124 \pm 2$ & $153 \pm 2$ & $54 \pm 2$ & $83 \pm 2$ & $8.4 \pm 0.1$ & $6.6 \pm 0.2$ \\
\hline PW Denmark strait & $-1.8 \pm 0.5$ & $-0.91 \pm 1.35$ & $34.07 \pm 0.27$ & $2,114 \pm 8$ & $2,266 \pm 3$ & $38 \pm 1$ & $110 \pm 3$ & $132 \pm 4$ & $42 \pm 3$ & $64 \pm 4$ & $6.9 \pm 0.4$ & $5.6 \pm 0.5$ \\
\hline \multicolumn{13}{|c|}{ AMOC upper limb (Density $>27.8$ ) } \\
\hline OW Faroes-shetland & $-2.0 \pm 0.3$ & $0.59 \pm 0.10$ & $34.91 \pm 0.02$ & $2,163 \pm 3$ & $2,303 \pm 3$ & $27 \pm 6$ & $100 \pm 2$ & $115 \pm 4$ & $2 \pm 2$ & $17 \pm 4$ & $8.1 \pm 0.0$ & $7.0 \pm 0.5$ \\
\hline $\mathrm{OW}_{\text {Iceland-Faroe }}$ & $-1.0 \pm 0.5$ & $0.33 \pm 0.30$ & $34.89 \pm 0.06$ & $2,156 \pm 5$ & $2,304 \pm 8$ & $33 \pm 4$ & $104 \pm 2$ & $123 \pm 5$ & $6 \pm 2$ & $25 \pm 5$ & $7.7 \pm 0.2$ & $6.4 \pm 0.1$ \\
\hline OW Denmark strait $_{\text {. }}$ & $-3.0 \pm 0.3$ & $1.47 \pm 0.45$ & $34.86 \pm 0.09$ & $2,148 \pm 6$ & $2,294 \pm 5$ & $37 \pm 2$ & $104 \pm 2$ & $124 \pm 3$ & $6 \pm 2$ & $27 \pm 3$ & $8.1 \pm 0.1$ & $6.6 \pm 0.2$ \\
\hline
\end{tabular}




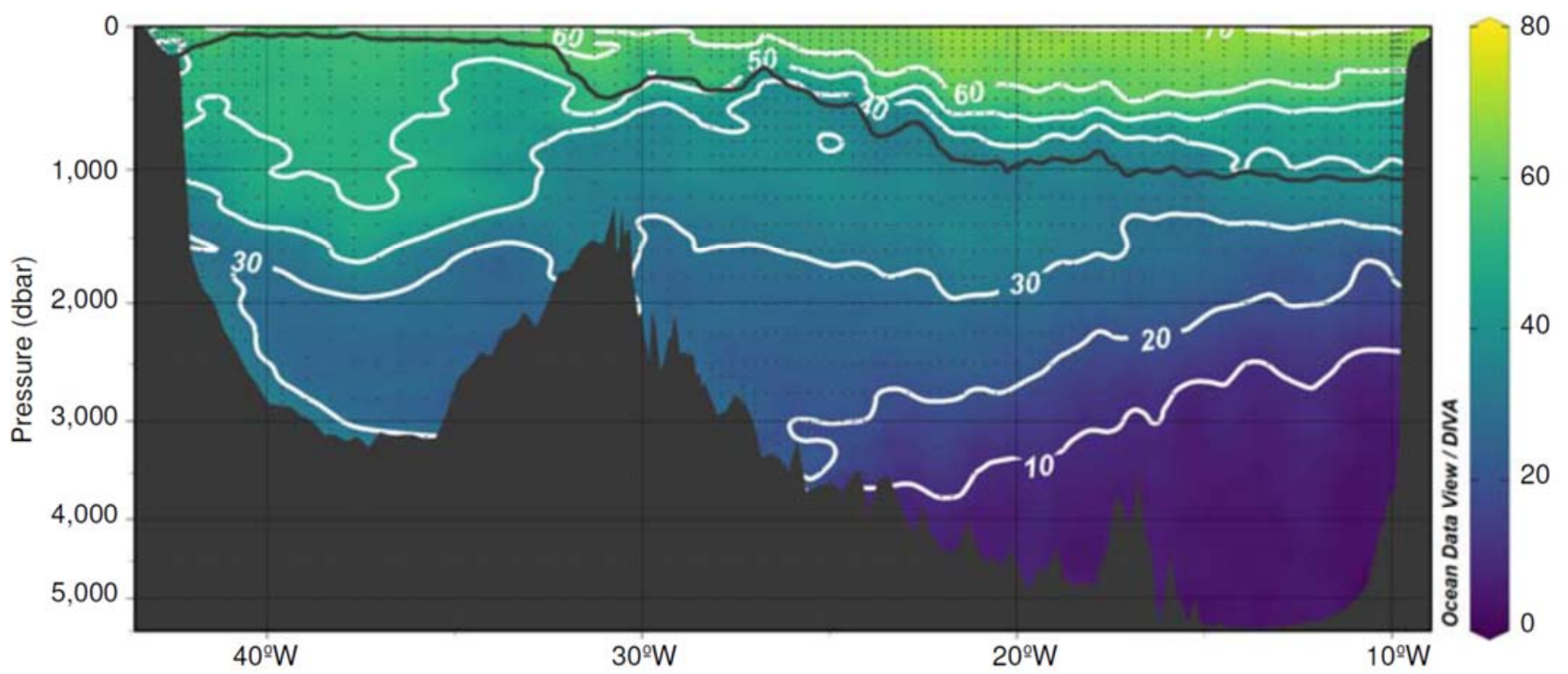

466 Extended Data Figure 1 | Anthropogenic $\mathrm{CO}_{2}$ along the 2016 Ovide section. Vertical

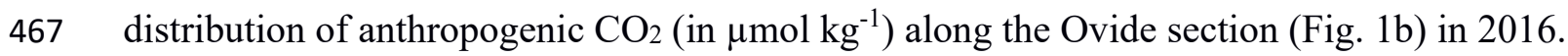

468 The black line is the isopycnal delimiting the upper and lower limbs of the AMOC.

469 


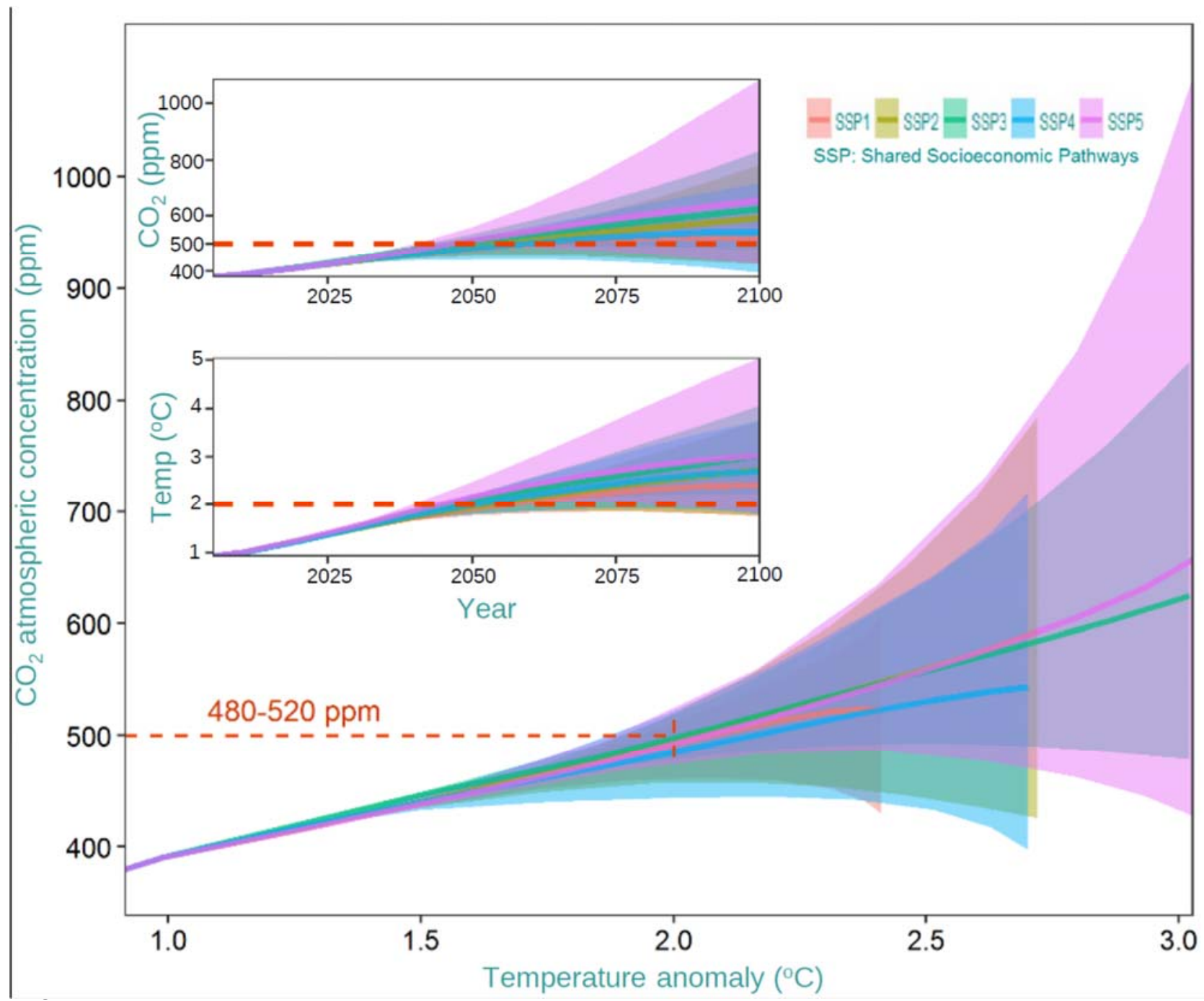

471 Extended Data Figure 2 | Projections of atmospheric $\mathrm{CO}_{2}$ and temperature change of

472 the five Shared Socioeconomic Pathways (SPP) ${ }^{24}$. Present: $1^{\circ} \mathrm{C}$ warming with

473 atmospheric $\mathrm{CO}_{2}$ concentration $\left(\left[\mathrm{CO}_{2}{ }^{\mathrm{atm}}\right]\right)$ of $400 \mathrm{ppm}^{21}$, which represents an atmospheric

$474 \mathrm{CO}_{2}$ excess $\left(\mathrm{xc}_{\mathrm{xc}}\left[\mathrm{CO}_{2}{ }^{\mathrm{atm}}\right]\right)$ of $120 \mathrm{ppm}\left(\mathrm{xc}_{\mathrm{xc}}\left[\mathrm{CO}_{2}{ }^{\mathrm{atm}}\right]=\left[\mathrm{CO}_{2}{ }^{\mathrm{atm}}\right]-280 \mathrm{ppm}\right.$; where $280 \mathrm{ppm}$ is

475 the pre-industrial $\left.\left[\mathrm{CO}_{2}{ }^{\mathrm{atm}}\right]\right)$. The doubling of atmospheric $\mathrm{C}_{\text {ant }}$ scenario, i.e. $2 \mathrm{x}$ present-day

$476 \mathrm{xc}\left[\mathrm{CO}_{2}{ }^{\mathrm{atm}}\right](480-520 \mathrm{ppm})$, is within the projection range for a $2^{\circ} \mathrm{C}$-warming scenario,

477 which could be reached in 2040-2052 according to SSP5 (pink shadowed area). SSP5 is the

478 only scenario that results in a radiative forcing as high as the former RCP8.5

479 (Representative Concentration Pathways) ${ }^{54}$. 

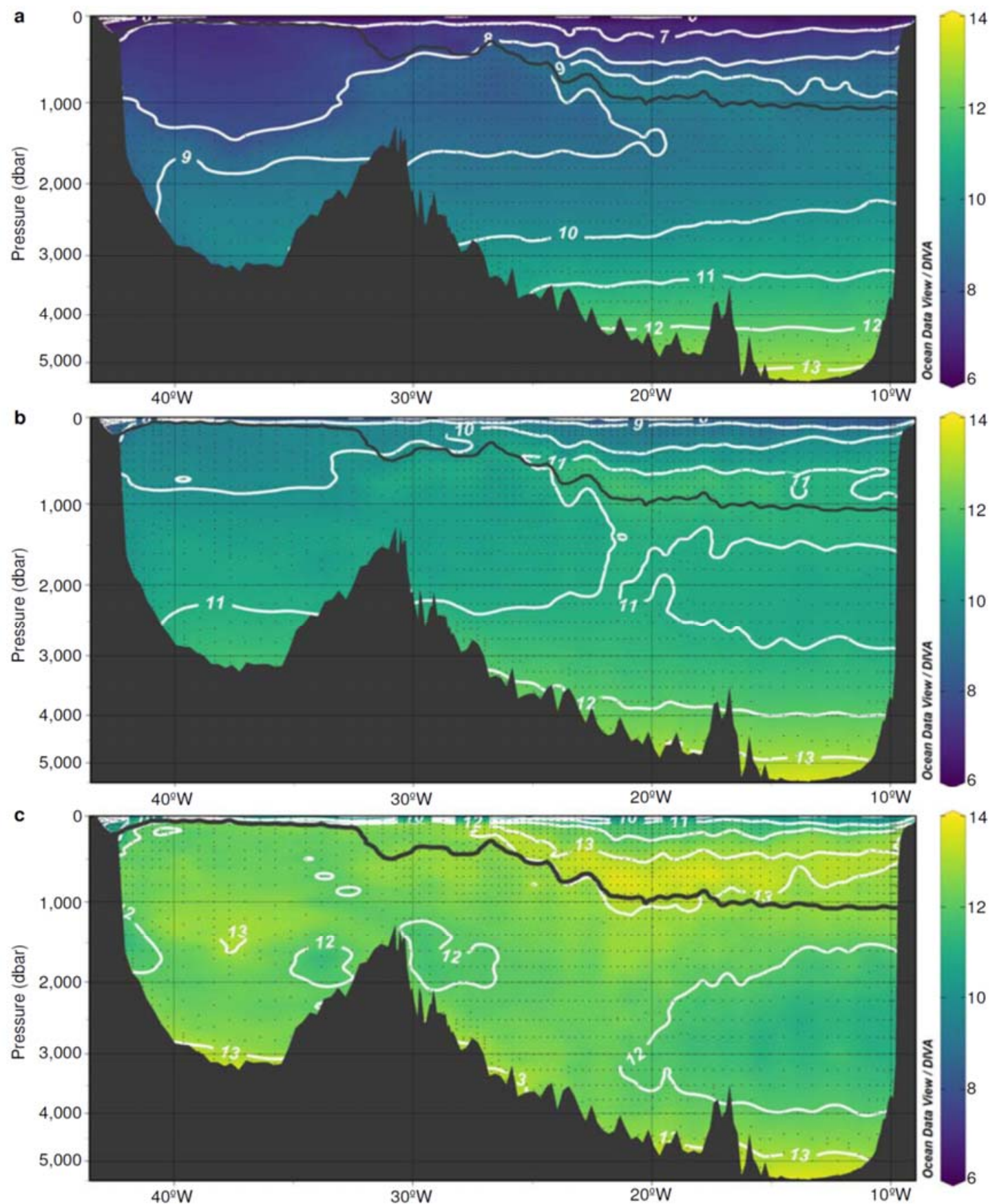
and lower limbs of the AMOC. 

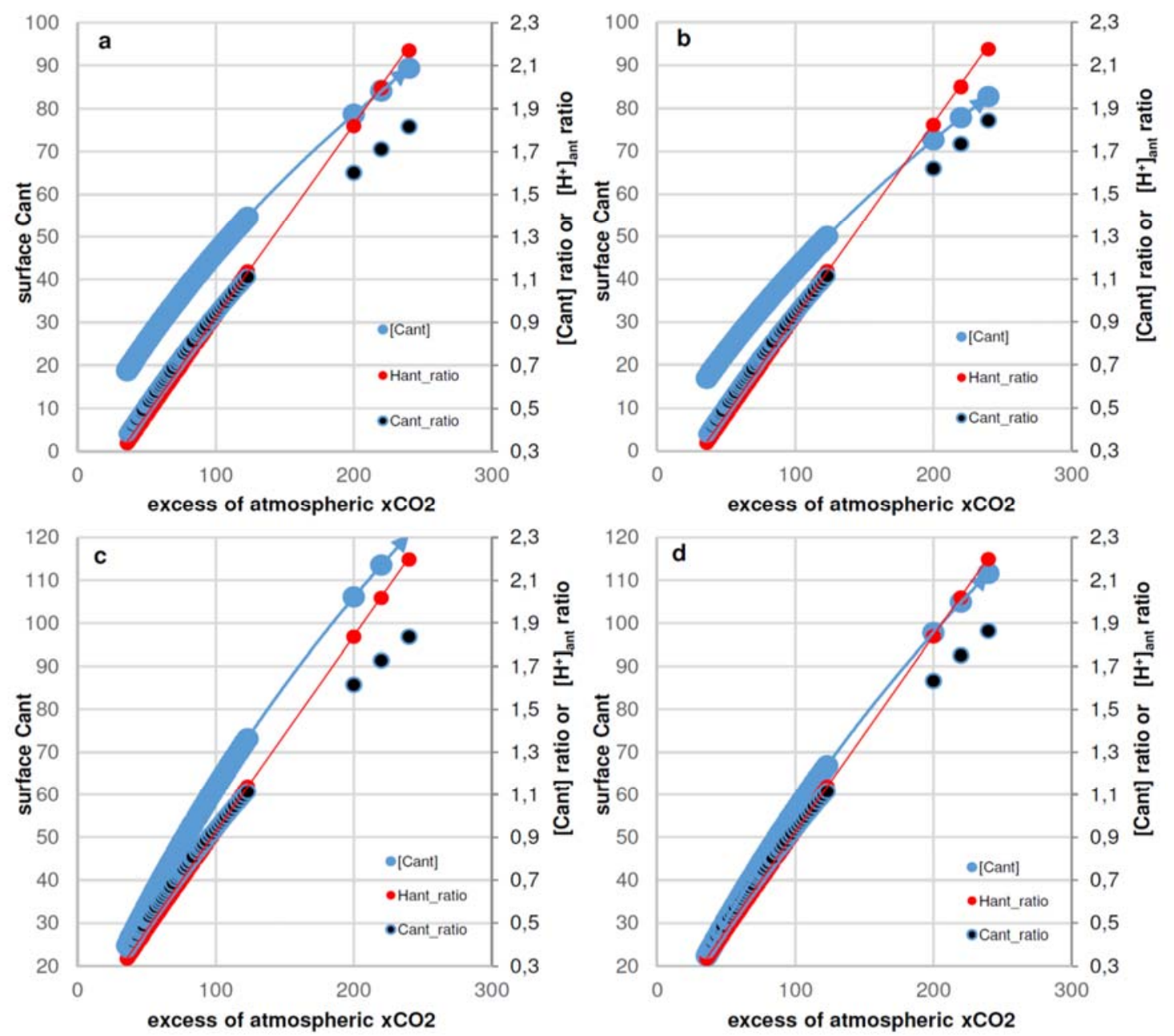

Extended Data Figure $4 \mid$ Progression of anthropogenic $\mathrm{CO}_{2}$ in surface waters versus excess of atmospheric $\mathrm{xCO}_{2}$ at different temperatures and $\mathrm{CO}_{2}$ disequilibriums. Concentration of anthropogenic $\mathrm{CO}_{2}\left([\mathrm{Cant}]\right.$, light blue dots, in $\mu \mathrm{mol} \mathrm{\textrm {kg } ^ { - 1 }}$ ), Cant_ratio (navy dots) and Hant ratio (red dots) versus the excess of atmospheric $\mathrm{xCO}_{2}$ due to anthropogenic signal during $1959-2016$ for (a) $2^{\circ} \mathrm{C}$ and $5 \%$ of $\mathrm{CO}_{2}$ disiquilibrium, (b) $2^{\circ} \mathrm{C}$ and $15 \%$ of $\mathrm{CO}_{2}$ disiquilibrium, (c) $20^{\circ} \mathrm{C}$ and $5 \%$ of $\mathrm{CO}_{2}$ disiquilibrium, and (d) $20^{\circ} \mathrm{C}$ and $15 \%$ of $\mathrm{CO}_{2}$ disiquilibrium. The Cant ratio (Hant ratio) is the ratio between the $\left[\mathrm{C}_{\mathrm{ant}}\right]$ $\left(\left[\mathrm{H}^{+}\right] \mathrm{ant}\right)$ at any time and the average $\left[\overline{\mathrm{C}}_{\mathrm{ant}}\right]\left(\left[\mathrm{H}^{+}\right] \mathrm{ant}\right)$ for the Ovide period $(2002-2016)$. The computed values for the doubling of atmospheric $\mathrm{C}_{\text {ant }}$ scenario (excess of atmospheric $\mathrm{xCO}_{2}$ of $220 \pm 20 \mathrm{ppm}$ ) are also shown. The progression of the Hant ratio fits to a straigh line, while, the Cant ratio decreases when increasing the atmospheric $\mathrm{xCO}_{2}$ due to the buffer capacity of the marine $\mathrm{CO}_{2}$ system (Revelle factor). An increase of $72 \pm 3 \%$ in $\mathrm{C}_{\text {ant }}$ above the average [ $\mathrm{C}_{\mathrm{ant}}$ ] for the Ovide period (2002-2016) is computed for the doubling of atmospheric $\mathrm{C}_{\mathrm{ant}}$ scenario. This is practicaly independent of the seawater temperature and the degree of $\mathrm{CO}_{2}$ disiquilibrium ${ }^{41}$. 


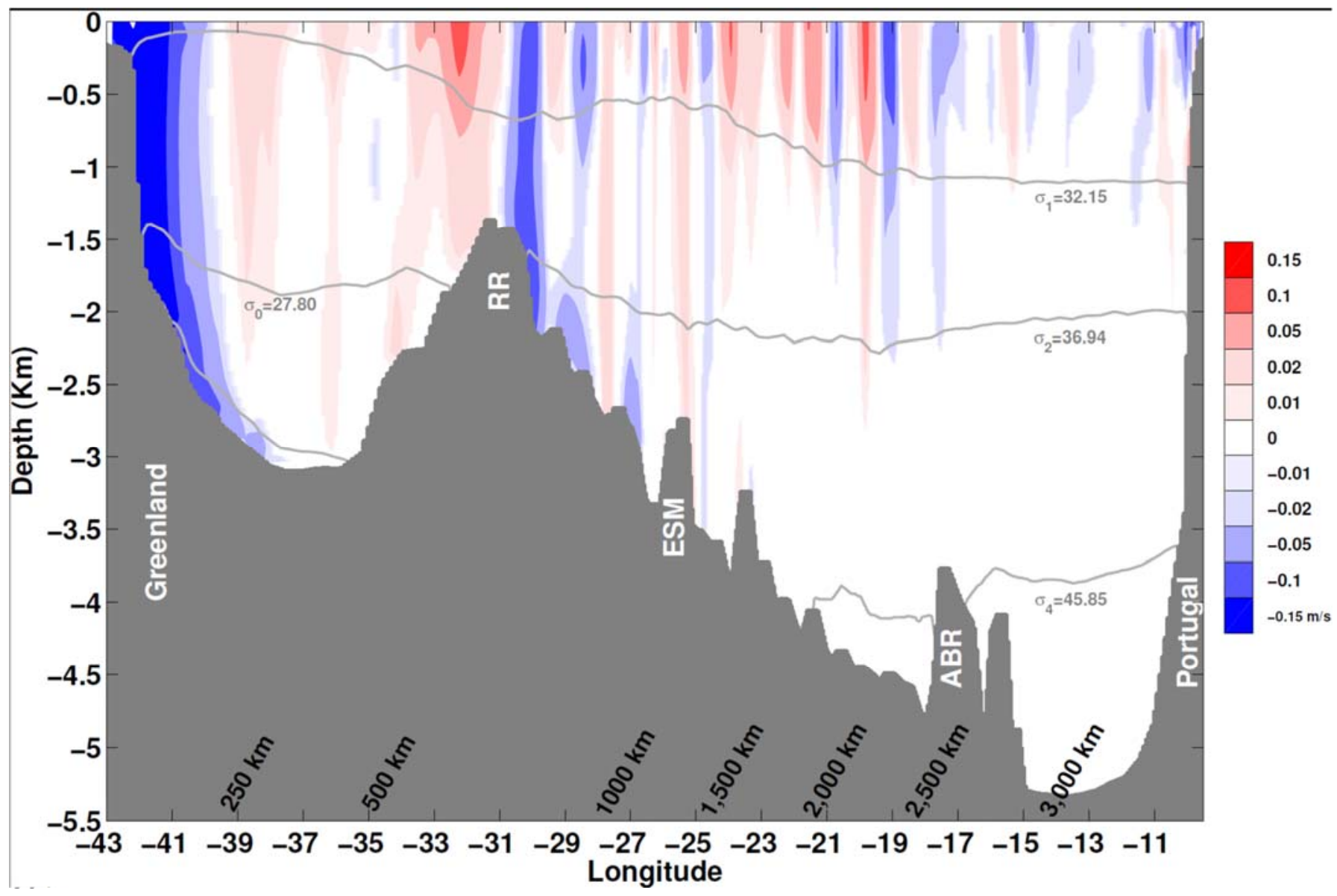

505 Extended Data Figure 5 | Mean velocities orthogonal to Ovide. Mean velocities (in $\mathrm{m} \mathrm{s}^{-}$

$506{ }^{1}$ ) orthogonal to the Ovide section for the period 2002-2016. The Ekman velocities,

507 estimated from winds stress averaged over the months of the cruises and equally distributed

508 over the first $30 \mathrm{~m}$, were added to the geostrophic velocities derived from a box inverse

509 model ${ }^{17,51-53}$. Positive (negative) velocities indicate northeastward (southwestward)

510 currents. The horizontal grey lines are the isopycnals $\sigma_{1}=32.15 \mathrm{~kg} \mathrm{~m}^{-3}, \sigma_{2}=36.94 \mathrm{~kg} \mathrm{~m}^{-3}$

511 and $\sigma_{4}=45.85 \mathrm{~kg} \mathrm{~m}^{-3}$. The $\mathrm{km}$ at the bottom of the figure indicates distance from

512 Greenland. The acronyms indicate topographic features: Reykjanes Ridge (RR), Eriador

513 Seamount (ESM) and Azores-Biscay Ridge (ABR). 


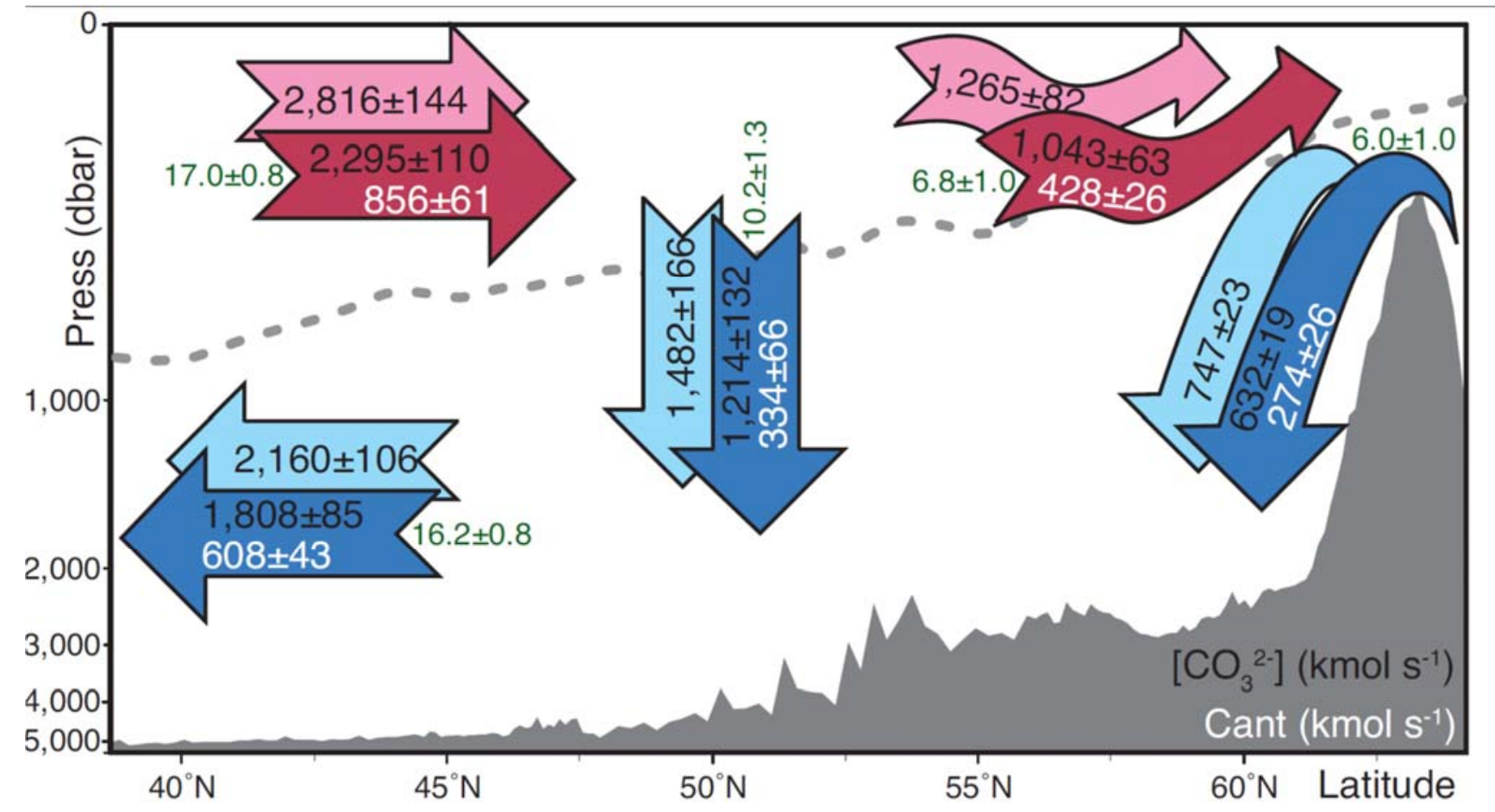

516 Extended Data Figure 6 | Circulation of carbonate ions and anthropogenic $\mathrm{CO}_{2}$ in the

517 Subpolar North Atlantic. Mean transports for 2002-2016 between the Ovide section and

518 the Nordic Sills of seawater (green values, in Sv), and natural (pre-industrial; light coloured

519 arrows) and observed (dark coloured arrows) carbonate ion concentration ( $\left[\mathrm{CO}_{3}{ }^{2-}\right]$, in kmol

$520 \mathrm{~s}^{-1}$, black values) and anthropogenic $\mathrm{CO}_{2}\left(\mathrm{C}_{\text {ant }}\right.$, in $\mathrm{kmol} \mathrm{s}^{-1}$, white values $)$. Uncertainties are

521 the errors of the mean transports across the eight occupations of the Ovide section $(\mathrm{std} / \sqrt{8})$.

522 Transports at the Nordic Sills derived from Jeansson et al. ${ }^{18}$ and Pérez et al. ${ }^{19}$. The grey

523 dotted line represents the limit between the upper and lower limbs of the AMOC.

524

525

526

527

528

529

530

Data availability: OVIDE cruise data from 2002 to 2010 are part of GLODAPv2 data product available at CDIAC Ocean $\mathrm{CO}_{2}$ Data (http://cdiac.ornl.gov/oceans).

OVIDE 2012 data was accessed from the Clivar \& Carbon Hydrographic Data Office (CCHDO; http://cchdo.ucsd.edu/cruise/29AH20120622), and OVIDE 2014 data is publicly available at http://www.obs-vlfr.fr/proof/ftpfree/geovide/ALKALINITY_PH/. The OVIDE 
2016 data that support the findings of this study are available at http://dx.doi.org/10.20350/digitalCSIC/8513.

\section{Acknowledgments}

The OVIDE research project was co-funded by IFREMER and CNRS/INSU/LEFE. H.M. was supported by CNRS. This is a contribution to AtlantOS project funded by the European Union's Horizon 2020 research and innovation programme under grant agreement No 633211. This study is also a contribution to the project BOCATS (CTM2013-41048-P) supported by the Spanish Ministry of Economy and Competitiveness and co-funded by the Fondo Europeo de Desarrollo Regional 2014-2020 (FEDER). We are grateful to the Captain of Sarmiento Gamboa, Anxeles Campos, and her crew for invaluable help that make possible the success of the BOCATS cruise. We are grateful to Des Barton for the English revision.

\section{Author contributions}

F.F.P., M.F., M.I.G-I. and H.M. contributed equally to this paper. F.F.P., H.M. and P.L. designed the program and F.F.P., H.M. and P.L. executed the field work. F.F.P, M.F., M.I.GI., A.V., M.P., F.A-P., E.F.G. and X.A.P. contributed to the chemical determination of nutrients and carbon system. H.M., P.L. and P.Z. contributed with the currents measurements and inverse model results. All authors contributed to discussion and writing.

\section{Competing financial interests}

The authors declare no competing financial interests.

\section{Additional information}

Supplementary information is available in the online version of the paper. Reprints and permissions information is available online at www.nature.com/reprints. Correspondence and requests for materials should be addressed to F.F.P. (fiz.perez@iim.csic.es) 